\title{
Comparison of primary and secondary particle formation from natural gas engine exhaust and of their volatility characteristics
}

\author{
Jenni Alanen $^{1}$, Pauli Simonen ${ }^{1}$, Sanna Saarikoski ${ }^{2}$, Hilkka Timonen $^{2}$, Oskari Kangasniemi ${ }^{1}$, Erkka Saukko ${ }^{1}$, \\ Risto Hillamo $^{2}$, Kati Lehtoranta ${ }^{3}$, Timo Murtonen ${ }^{3}$, Hannu Vesala $^{3}$, Jorma Keskinen ${ }^{1}$, and Topi Rönkkö ${ }^{1}$ \\ ${ }^{1}$ Aerosol Physics, Faculty of Natural Sciences, Tampere University of Technology, P.O. Box 692, Tampere, Finland \\ ${ }^{2}$ Atmospheric Composition Research, Finnish Meteorological Institute, P.O. Box 503, Helsinki, Finland \\ ${ }^{3}$ VTT Technical Research Centre of Finland Ltd., P.O. Box 1000, Espoo, Finland
}

Correspondence to: Topi Rönkkö (topi.ronkko@ tut.fi)

Received: 26 January 2017 - Discussion started: 8 February 2017

Revised: 15 May 2017 - Accepted: 6 June 2017 - Published: 18 July 2017

\begin{abstract}
Natural gas usage in the traffic and energy production sectors is a growing trend worldwide; thus, an assessment of its effects on air quality, human health and climate is required. Engine exhaust is a source of primary particulate emissions and secondary aerosol precursors, which both contribute to air quality and can cause adverse health effects. Technologies, such as cleaner engines or fuels, that produce less primary and secondary aerosols could potentially significantly decrease atmospheric particle concentrations and their adverse effects. In this study, we used a potential aerosol mass (PAM) chamber to investigate the secondary aerosol formation potential of natural gas engine exhaust. The PAM chamber was used with a constant UV-light voltage, which resulted in relatively long equivalent atmospheric ages of 11 days at most. The studied retro-fitted natural gas engine exhaust was observed to form secondary aerosol. The mass of the total aged particles, i.e., particle mass measured downstream of the PAM chamber, was 6-268 times as high as the mass of the emitted primary exhaust particles. The secondary organic aerosol (SOA) formation potential was measured to be $9-20 \mathrm{mg} \mathrm{kg}_{\text {fuel }}^{-1}$. The total aged particles mainly consisted of organic matter, nitrate, sulfate and ammonium, with the fractions depending on exhaust after-treatment and the engine parameters used. Also, the volatility, composition and concentration of the total aged particles were found to depend on the engine operating mode, catalyst temperature and catalyst type. For example, a high catalyst temperature promoted the formation of sulfate particles, whereas a low catalyst temperature promoted nitrate formation. However, in particular, the concentration of nitrate needed a long time
\end{abstract}

to stabilize - more than half an hour - which complicated the conclusions but also indicates the sensitivity of nitrate measurements on experimental parameters such as emission source and system temperatures. Sulfate was measured to have the highest evaporation temperature, and nitrate had the lowest. The evaporation temperature of ammonium depended on the fractions of nitrate and sulfate in the particles. The average volatility of the total aged particles was measured to be lower than that of primary particles, indicating better stability of the aged natural gas engine-emitted aerosol in the atmosphere. According to the results of this study, the exhaust of a natural gas engine equipped with a catalyst forms secondary aerosol when the atmospheric ages in a PAM chamber are several days long. The secondary aerosol matter has different physical characteristics from those of primary particulate emissions.

\section{Introduction}

Primary aerosol particles are directly emitted into the atmosphere by various anthropogenic sources, such as vehicles, engines and power plants, and biogenic sources. Secondary aerosol particle mass forms as a consequence of the atmospheric oxidation of emitted precursor gases. In this process, the saturation vapor pressure of the organic and inorganic gases becomes lower, thus allowing them to transfer into particle phase through condensation and nucleation (Hallquist et al., 2009; Murphy et al., 2014). In addition to biogenic sources, also traffic and other anthropogenic sources con- 
tribute to secondary aerosol formation (Kanakidou et al., 2005).

Fine particles $(<2.5 \mu \mathrm{m})$ are found to cause adverse health effects and premature mortality in people (Dockery and Pope III, 1994; Lelieveld et al., 2015). The relative contribution of primary and secondary particles to these health effects is still unknown, but there are indications that secondary particles can be even more hazardous than primary particles (Künzi et al., 2015; McWhinney et al., 2011; Rager et al., 2011). Therefore, both primary and secondary particle emissions must be taken into consideration when evaluating the health effects of particle emissions.

Aerosols play an important role in the climate as well. Fine particles in the atmosphere affect the radiative balance of the atmosphere by either warming or cooling it, depending on their properties (Myhre et al., 2013); however, large uncertainties remain regarding the contribution of particles to climate change and its prevention. Clouds also contribute to the atmosphere's radiative balance. Aging of an aerosol can lead to increased hygroscopicity of the particles (Kanakidou et al., 2005) and a higher likelihood that they act as cloud condensation nuclei. The preservation and lifetime of the particles in the atmosphere partly define how large their impact is on the climate.

The formation process of secondary inorganic aerosol can be modeled rather accurately because the number of different inorganic precursors is small and their oxidation reactions are well known. Secondary organic aerosol (SOA) is a more complex subject area due to the vast number of different organic compounds, their potential reactions and the still unknown participation of all compounds in secondary aerosol formation (Hallquist et al., 2013; Jimenez et al., 2009). SOA has been a hot topic in aerosol science during the past decade (Huang et al., 2014; Robinson et al., 2007; Virtanen et al., 2010), but there are still many open questions in considering, for example, the SOA formation from vehicle emissions (Gentner et al., 2017). Also, the relative fractions of secondary organic and inorganic aerosol from various emission sources still need to be studied. Both secondary organic and secondary inorganic aerosol can contribute significantly to air quality deterioration (Huang et al., 2014).

Particle number and mass emission regulations for passenger cars and heavy-duty engines have substantially decreased the primary particle emissions from vehicles (e.g., May et al., 2014; Johnson, 2009). Secondary particle precursor emissions or secondary aerosol formation potential are not directly regulated, but some of the current emission regulations affect secondary particle precursor emissions indirectly. For instance, oxidative catalysts reduce the total hydrocarbon emissions and thus probably the emissions of secondary organic aerosol precursors; simultaneously, they also change the oxidation state of inorganic compounds. Furthermore, the mandatory national targets of $10 \%$ biofuel (ethanol) in gasoline in EU may have decreased the SOA formation in the atmosphere (Timonen et al., 2017). In general, vehicles emit a substantial fraction of anthropogenic precursors for SOA formation (Gentner et al., 2017), and the amount of potential SOA often exceeds the emissions of primary organic aerosol. For instance, gasoline vehicles emit 9-15 times or even 2 orders of magnitude higher secondary organic particulate matter than primary organic particle mass (Karjalainen et al., 2016; Nordin et al., 2013; Platt et al., 2013; Tkacik et al., 2014). Indeed, Bahreini et al. (2012) found that secondary organic aerosol originating from gasoline engines forms the majority of the SOA in and downwind of large metropoli$\tan$ areas. From diesel vehicles without a particle filter, the SOA mass formation potential is of the same magnitude as or lower than the primary particle mass emission (Jathar et al., 2017; Gordon et al., 2014b; Weitkamp et al., 2007).

Exhaust after-treatment can reduce secondary aerosol formation potential from engine exhaust, especially SOA formation potential. In general, diesel fuel has the strongest secondary organic aerosol formation potential amongst diesel, jet fuel, gasoline and the Fischer-Tropsch fuels from natural gas (NG) and coal (Jathar et al., 2013). However, diesel vehicles equipped with oxidation catalysts or catalytic particle filters have been reported to be minor secondary particle emitters (Chirico et al., 2010; Gordon et al., 2014b; Samy and Zielinska, 2010). In gasoline engine functioning, exhaust after-treatment can also clearly reduce secondary particle formation (Karjalainen et al., 2016). The secondary aerosol precursor emissions of engines and vehicles are also strongly dependent on the driving conditions, which should be taken into account in emission comparisons.

For instance, Tkacik et al. (2014) showed that the secondary inorganic mass often exceeds the amount of the secondary organic aerosol in a highway tunnel, even by a factor of 2. The main contributor to secondary inorganic aerosol in their study was ammonium nitrate, which originates from $\mathrm{NO}_{x}$ and ammonia emissions. According to Karjalainen et al. (2016), large fractions of nitrate in the secondary inorganic particles are characteristic for highway driving, and the inorganic species concentrations are relatively low when compared with the secondary organic aerosol formed during other parts of the New European Driving Cycle (NEDC), which they tested. Idling is another engine operation mode that can produce significant amounts of secondary inorganic aerosol from gasoline vehicle exhaust (Nordin et al., 2013).

Natural gas usage as a fuel in combustion engines, both in energy production and traffic, is a growing trend worldwide. Natural gas engines emit little primary particle mass and less $\mathrm{CO}_{2}$ than engines fueled with conventional fuels (Anderson et al., 2015; Bielaczyc et al., 2014) but their particle number emission can be significant (Hallquist et al., 2013; Jayaratne et al., 2010). In addition, the size of the majority of the particles emitted by natural gas engines can be below the detection limits of traditional exhaust particle measurement devices (Alanen et al., 2015). Natural gas engine exhaust particles are highly volatile (Bullock and Olfert, 2014; Jayaratne et al., 2012) or they can consist of volatile mat- 
ter condensed on non-volatile cores (Alanen et al., 2015; Graves et al., 2015; Pirjola et al., 2016). The evaporation of the particles is largest at temperatures below $100^{\circ} \mathrm{C}$ (Alanen et al., 2015; Jayaratne et al., 2012). Primary particles from natural gas engines mainly consist of organic matter (Pirjola et al., 2016), but the composition depends on exhaust aftertreatment (Lehtoranta et al., 2017). In the study of Lehtoranta et al. (2017), high catalyst temperatures were found to increase the fraction of sulfate in particles when a combination of oxidative and reductive catalysts was employed. Also, increased ammonium concentrations were found in particles at high catalyst temperatures.

To the authors' knowledge, there are no published studies on secondary particle formation from natural gas engine emissions, its chemical or physical properties or the effect of exhaust after-treatment on exhaust's secondary particle formation. Goyal and Sidhartha (2003) recorded a notable improvement in the air quality of Delhi when a portion of vehicles were changed to natural gas vehicles in 2001. In our study, the secondary aerosol formation potential of natural gas engine exhaust was investigated using a flow-through reactor, and the chemical and physical characteristics of particles were investigated by aerosol instruments. The results were compared to those of primary particle emissions, but because the primary particle emissions of the same engine have already been discussed in two earlier publications (Alanen et al., 2015; Lehtoranta et al., 2017), they are not a focus of this paper. In general, the aim of this study is to report the total particulate emissions of natural gas engines, i.e., primary and secondary particles, to ensure that shifting to natural gas from diesel and gasoline will not cause unexpected environmental or health issues, and to define the possible benefits of the shift. Volatility studies on both primary and secondary particles enabled an evaluation of the stability and residence time of the particles in the atmosphere. The study of chemical composition can help solve their origin and find ways to reduce the particulate emissions.

\section{Methods}

\subsection{Engine and after-treatment}

A small (2.0 L displacement) spark-ignited passenger car engine was used for the measurements with Russian pipeline natural gas as fuel. The methane content of the fuel was $97 \%$, other hydrocarbon content was $1.6 \%$ and nitrogen content was $0.9 \%$. The sulfur content was below $1 \mathrm{ppm}$. The engine was run at two steady-state engine operation modes with torque of $70 \mathrm{Nm}$ and speed of $2700 \mathrm{rpm}$ (mode 1, M1) and torque of $35 \mathrm{Nm}$ and speed of $3100 \mathrm{rpm}$ (mode 2, M2). In engine mode 2, short-chain hydrocarbons were added into the exhaust to make it resemble the exhaust of a power plant NG engine. The exhaust gas composition in two operation modes simulated typical natural gas power plant exhaust gas compo- sition. The engine, natural gas and lubricating oil properties as well as the engine operation modes have been described in more detail by Murtonen et al. (2016), Alanen et al. (2015) and Lehtoranta et al. (2017).

Two separate after-treatment systems were applied in the measurements, both consisting of a reductive and an oxidative section. The after-treatment has been described in more detail by Lehtoranta et al. (2017). The first catalyst (catalyst $1, \mathrm{C} 1$ ) consisted of only one reactor, which targeted both oxidation of carbon compounds and $\mathrm{NO}_{x}$ reduction through urea injection in the same catalyst reactor. The second catalyst system (catalyst 2, C2) consisted of a palladium- and platinum-containing methane oxidation catalyst followed by urea injection and a vanadium-SCR (selective catalyst reduction) catalyst, which were supported on metallic honeycomb substrates. Catalyst 1 was used in three different exhaust temperatures in the range of $350-450^{\circ} \mathrm{C}$ in order to study its performance and its influence on secondary particle formation potential of the engine exhaust. The temperature of the catalyst 2 was $500{ }^{\circ} \mathrm{C}$. Catalyst performance depends on the exhaust temperature (e.g., Lehtoranta et al., 2017). By using the catalysts at different temperatures, effects of catalyst temperature on the formation and characteristics of primary and total aged particulate matter could be studied. The catalyst temperatures were measured upstream of the oxidation catalysts. The temperature prior to the SCR of catalyst 2 was approximately $50^{\circ} \mathrm{C}$ lower than prior to the oxidation catalyst. The exhaust flow through the catalysts was kept constant at $80 \mathrm{~kg} \mathrm{~h}^{-1}$ by leading only a part of the exhaust gas flow through them (Murtonen et al., 2016).

\subsection{Instrumentation and data analysis}

The sampling system or the particle measurement instruments consisted of a porous tube diluter (PTD, Mikkanen et al., 2001; Ntziachristos et al., 2004) with a dilution ratio (DR) of 6 , followed by a residence time chamber with a residence time of $6 \mathrm{~s}$. The low primary dilution ratio was used because of the very low primary particle emission concentrations (see Alanen et al., 2015). The dilution air was heated to $30^{\circ} \mathrm{C}$ to achieve constant dilution conditions. A second dilution stage was carried out with an ejector diluter (Dekati Ltd.) with DR 4. The dilution ratio over the PTD was adjusted using a bypass flow mass flow controller placed downstream of the residence time chamber (Fig. 1). The dilution ratios were calculated from $\mathrm{CO}_{2}$ concentrations in the raw and diluted exhaust samples and they could be used to calculate tailpipe concentrations of particle emissions. The aerosol sampling was done downstream of the exhaust after-treatment system.

A potential aerosol mass (PAM) chamber (Kang et al., 2007, 2011; Lambe et al., 2011, 2015) was used to simulate the aging process of an aerosol in the atmosphere. In the PAM, an oxidative environment $\left(\mathrm{O}_{3}, \mathrm{OH}\right.$ and $\mathrm{HO}_{2}, \mathrm{UV}$ light $)$ was produced using two UV lamps emitting 185 and $254 \mathrm{~nm}$ radiation, respectively, in a small $(13 \mathrm{~L})$ flow-through cham- 


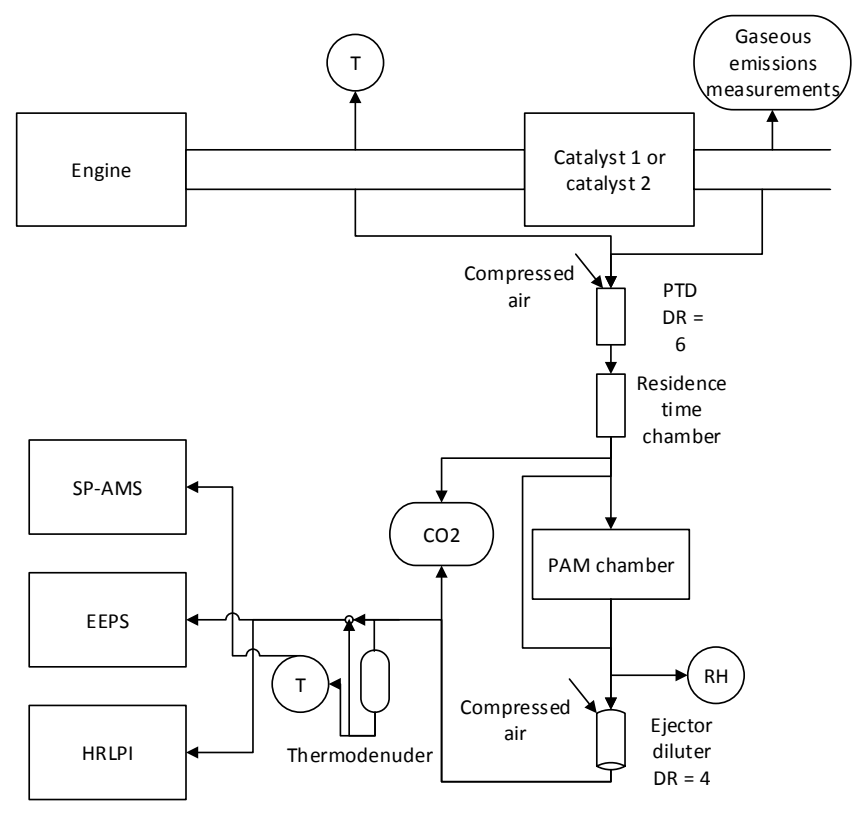

Figure 1. A schematic picture of the measurement setup.

ber. The PAM chamber was placed between the two dilution stages, and the flow through it was a constant $5 \mathrm{~L} \mathrm{~min}^{-} 1$ (residence time $156 \mathrm{~s}$ ), measured by a bubble flow meter (Gilibrator, Sensidyne Inc.) and adjusted by a pressure regulator of the compressed air flow to the ejector diluter. The PAM chamber could be either bypassed or used to measure the properties of primary and secondary aerosols, respectively.

The approximate atmospheric age, i.e., the photochemical age simulated by the PAM chamber UV lights, was modeled using the properties of the PAM chamber and the measured concentrations of gaseous components that cause external $\mathrm{OH}$ reactivity in the chamber. The model used for calculating the $\mathrm{OH}$ exposures was based on the degradation mechanism extracted from the Master Chemical Mechanism or MCM v3.3.1 (Jenkin et al., 1997, 2003; Saunders et al., 2003) via the website http://mcm.leeds.ac.uk/MCM and translated to Matlab code using the kinetic preprocessor or KPP (Damian et al., 2002). The model has been tested against $\mathrm{SO}_{2}$ reduction measurements in the PAM chamber.

MCM is a near-explicit chemical mechanism that describes the atmospheric degradation of volatile organic compounds in gas phase. MCM describes the degradation of a given volatile organic compound (VOC) through different generations of products until $\mathrm{CO}_{2}$ is ultimately formed. It contains about 17000 reactions for 6700 different species (Jenkin et al., 1997, 2003; Saunders et al., 2003). To be able to use these mechanisms with the PAM chamber, the photolysis rates have been calculated for ultraviolet light with wavelengths of 185 and $254 \mathrm{~nm}$. The absorption cross section and quantum yield values needed for this are IUPAC recommendations (Atkinson et al., 2007) supplemented with the Jet Propulsion Laboratory (JPL) data evaluation number 18
(Burkholder et al., 2015) when necessary. Some photolysis reactions that are relevant to the PAM chamber but missing from the tropospheric MCM schemes have also been added.

KPP is a software tool for translating kinetic chemical mechanisms into Fortran 77, Fortran 90, C or MATLAB simulation code. The generated code produces concentrations of each species present as a function of time (Damian et al., 2002). For the model used, the KPP source code was modified to fix certain conflicts involving the MCM mechanism and the photolysis rate calculations written for the PAM chamber, as well as to allow large chemical schemes typical to MCM.

In this paper, we describe the PAM OH exposure as photochemical age, which is the equivalent time in the atmosphere in which the sample would reach the same $\mathrm{OH}$ exposure as in the PAM chamber. Thus,

Photochemical age (days) $=$

$\frac{\text { OH exposure }}{1.5 \times 10^{6}{\text { molec } \mathrm{cm}^{-3}}^{-3}} \frac{1}{3600 \mathrm{~h}^{-1} \mathrm{~s} \times 24 \mathrm{~d}^{-1} \mathrm{~h}}$,

where $1.5 \times 10^{6}$ molec $^{-3}$ is the average $\mathrm{OH}$ concentration in the atmosphere (Mao et al., 2009).

Relative humidity (RH) was measured downstream of the PAM chamber. The RH was high, about $80 \%$, due to the low primary dilution ratio that was applied during the experiments. The high RH of the sample complicated the evaluation of the PAM background mass levels - i.e., the particulate mass that was generated by only compressed air and UV lights - because the high RH could not be reproduced in the compressed air by the available instrumentation. The background levels were measured using both dry compressed air and compressed air with $\mathrm{RH} \sim 30 \%$.

$\mathrm{NO}_{x}$ concentration was measured with a chemiluminescence detector (CLD), $\mathrm{CO}$ and $\mathrm{CO}_{2}$ concentrations in raw exhaust were measured with a non-dispersive infrared (NDIR) analyzer and $\mathrm{CO}_{2}$ concentrations in diluted exhaust were measured with a Sick Maihak SIDOR gas analyzer. Water, methane, $\mathrm{NH}_{3}, \mathrm{HNCO}$ and the ratio of $\mathrm{NO}$ and $\mathrm{NO}_{2}$ were measured with a Fourier transform infrared spectroscopy (FTIR, Gasmet Cr-2000) analyzer, and methane, ethane, propane and ethylene were measured with a gas chromatograph (GC).

Aerosol instruments covered a large range of particle mobility and aerodynamic size as well as measurements of the particles' chemical composition. An engine exhaust particle sizer (EEPS, TSI Inc., Mirme, 1994) and a high-resolution low-pressure impactor (HRLPI, Arffman et al., 2014) were employed, both on $1 \mathrm{~s}$ time resolution, to measure the particle number, mass and size. The EEPS measures the size distribution and concentration of particles with a mobility diameter of 5.6-560 nm, and the HRLPI measures the aerodynamic size distribution of particles with diameter of $\sim 5-200 \mathrm{~nm}$. The mass of the particles was calculated under assumptions 
of unit density and spherical particles. EEPS default inversion was applied.

A soot particle aerosol mass spectrometer (SP-AMS, Aerodyne Research Inc., US) - a combination of a highresolution time-of-flight aerosol mass spectrometer and a single particle soot photometer (Droplet Measurement Technologies) - was used to measure the chemical composition and oxidative state of the aerosol sample. The SP-AMS measures both refractory and non-refractory particulate matter. It operated in $\mathrm{V}$ mode with a 1 min time resolution, measuring half of the time in mass spectra (MS) mode and the other half in particle size (pToF) mode. Both laser and tungsten vaporizers were used. The collection efficiency applied in the calculations was calculated using the parameterization by Middlebrook et al. (2012). The $\mathrm{CO}_{2}$ gas interference in the AMS data was corrected by using the $\mathrm{CO}_{2}$ concentrations measured with the Sick Maihak SIDOR gas analyzer. The impact of ammonium nitrate interference on $\mathrm{CO}_{2}^{+}, \mathrm{O}: \mathrm{C}$ and $\mathrm{H}: \mathrm{C}$ ratios was evaluated to be small (less than $5 \%$ for $\mathrm{O}: \mathrm{C}$ and $\mathrm{H}: \mathrm{C}$; Pieber et al., 2016). Therefore, a correction of ammonium nitrate interference was not applied for organics or $\mathrm{O}: \mathrm{C}$ data.

Volatility measurements were made with a thermodenuder (TD) described in the publication by Heikkilä et al. (2009). When the remaining mass of particles was measured as a function of TD temperature, the thermodenuder was heated up to $265^{\circ} \mathrm{C}$ and then switched off, with the sample flow still flowing through it. The decreasing temperature was recorded for at least half an hour until the temperature was below $50{ }^{\circ} \mathrm{C}$.

Emission factors were calculated from fuel composition and engine performance information. Residual $\mathrm{O}_{2}$ in the exhaust was $6.2-6.3 \%$, the power of the engine was 12 and $20 \mathrm{~kW}$ and the combustion air flow into the engine was approximately 100 and $115 \mathrm{~kg} \mathrm{~h}^{-1}$ in engine modes 1 and 2, respectively. Calculated from the fuel composition information, the emission factor for $\mathrm{CO}_{2} \mathrm{EF}_{\mathrm{CO}_{2}}$ was $2730 \mathrm{~g} \mathrm{~kg}_{\text {fuel }}^{-1}$, and the carbon intensity was $0.74 \mathrm{~kg}_{\mathrm{C}} \mathrm{kg}_{\text {fuel }}^{-1}$.

\section{Results and discussion}

\subsection{Secondary particle formation and chemical composition}

The concept "total aged" here comprises all particle mass measured downstream of the PAM chamber, i.e., both primary and secondary particle mass. In general, primary particle mass has not been subtracted from the mass measured downstream of the PAM (total aged) to calculate the secondary particle mass separately because doing so would have created inconsistency in representation of the results, since, for example, particle size distributions or volatility behavior cannot be presented in this way. For the same reasons, the PAM background mass - i.e., the particle mass generated in the PAM chamber from clean compressed air - has not been subtracted but is instead presented separately in the Supplement of this paper. To enable a comparison to literature, an exception is made when presenting secondary particle production factors (PFs).

Figure 2 contains particulate mass measurement results derived from the three aerosol instruments. The chemical compositions from SP-AMS are also presented. The cases (engine mode, catalyst and catalyst temperature) included in this paper cover all of the tested exhaust temperatures and both engine operation modes, and they have data collected with all available instruments of both the primary and total aged aerosol measurements. In most cases in our measurements, primary exhaust particle mass concentrations from the natural gas engine were close to the detection limits of the instruments EEPS, HRLPI and SP-AMS (Alanen et al., 2015; Lehtoranta et al., 2017). Exceptions were made by the high temperature catalyst cases $\left(\mathrm{M} 2, \mathrm{C} 2,500^{\circ} \mathrm{C}\right.$ and $\mathrm{M} 2, \mathrm{C} 1,450^{\circ} \mathrm{C}$ ) during which more primary particle mass was formed, especially on the size ranges of the HRLPI and EEPS: a high catalyst temperature favors the conversion of $\mathrm{SO}_{2}$ into $\mathrm{SO}_{3}$ and further into sulfuric acid, which can nucleate and condense on existing particles in the sampling process or when released into the atmosphere (see, e.g., Arnold et al., 2012; Rönkkö et al., 2013). The primary particle formation phenomena and concentrations have been discussed in more detail in Lehtoranta et al. (2017) while this paper focuses on secondary aerosol formation and the total aged particle emissions.

The formed secondary particle mass concentrations were found to be significantly high in comparison with the primary particle mass emissions. In all of the investigated cases, particle mass increased when the sample was led through the PAM chamber. The increase in mass could be magnitudes larger than the primary particle mass emission (Table 1). The relative increase in mass in the PAM chamber could not be specified for all of the HRLPI measurements because of the very low primary particle mass. The total aged aerosol mass produced by natural gas engine exhaust was $0.99-2.6 \mathrm{mg} \mathrm{m}^{-3}$ according to SP-AMS, leading to secondary mass production of $0.96-2.5 \mathrm{mg} \mathrm{m}^{-3}$.

The secondary aerosol formation - i.e., the ratio of the total aged particulate mass to the primary particulate mass was lower in the cases that already produced more primary particle mass, i.e., in the cases with a high catalyst temperature. It is possible that if the catalyst conditions are favorable, the particulate matter that would otherwise condense on particles in the PAM chamber condenses on the particle phase already in the cooling and dilution processes. In other words, if the catalyst sufficiently oxidizes the exhaust gases, thus lowering their saturation vapor pressure, they condense or nucleate already when released from the tailpipe and not later on in the atmosphere. A high catalyst temperature promoted larger total aged aerosol formation, according to the EEPS and HRLPI measurements. However, the total aged 


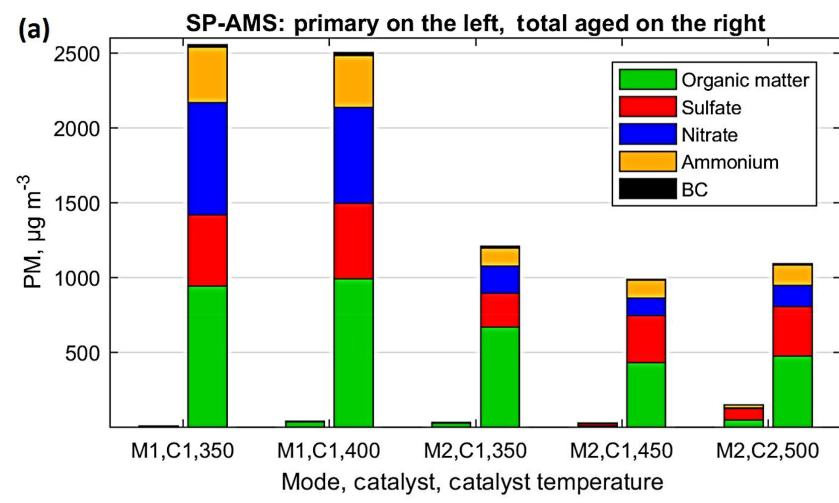

(b)
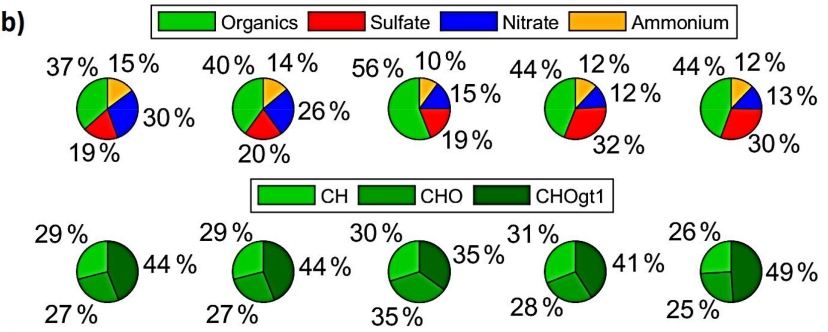

(c)

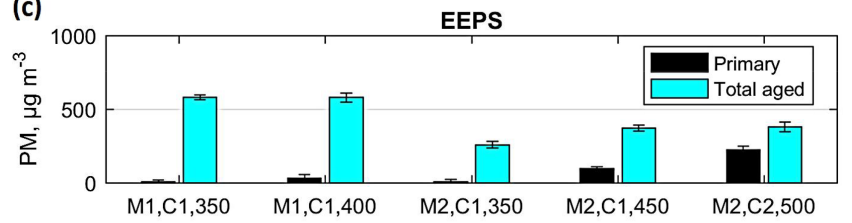

(d) HRLPI

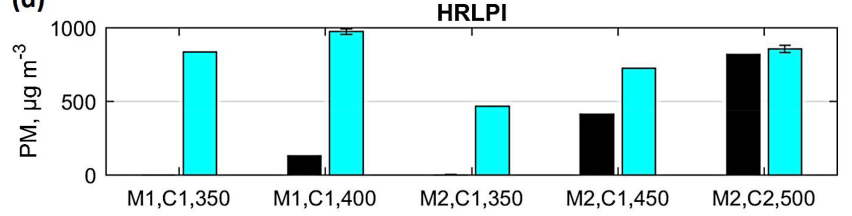

Figure 2. Exhaust primary and total aged particle mass concentrations measured by (a) SP-AMS, (c) EEPS and (d) HRLPI at different engine modes and catalyst temperatures. All values have been corrected by dilution ratio used in the sampling system. Secondary particle mass can be calculated by subtracting primary from total aged emission. The composition of the total aged particulate matter and the organic particulate matter is presented as pie charts (b). The fraction of black carbon is less than or equal to $1 \%$ and therefore left out from the pie charts.

mass concentrations of the SP-AMS did not increase as catalyst temperature increased. The differences in the instruments' showings are discussed in Sect. 3.3. Also, the variation in the atmospheric ages increases uncertainty in the comparison of the catalyst temperature on secondary aerosol formation potential.

The total aged aerosol of the natural gas engine exhaust consisted of both organic and inorganic matter at the tested operating conditions (Fig. 2, Table 1). Approximately half of the total aged aerosol particle mass detected by SP-AMS consisted of organic matter. The fraction of sulfate and nitrate was measured to be $34-49 \%$ in total, with their ra- tio depending on the case, and the fraction of ammonium varied between 10 and $15 \%$. Link et al. (2017) found that even high $\mathrm{NO}_{x}$ emissions can produce negligible amounts of secondary nitrate aerosol if related ammonia emissions are small. Because secondary ammonium nitrate aerosol formation is limited by ammonia, its formation is probably more related to the exhaust after-treatment than the fuel. The exact ammonia concentrations in the raw exhaust cannot be given because they were below the instrument detection limit of $2 \mathrm{ppm}$. According to these measurements, also low ammonia emissions may have atmospheric importance as secondary inorganic aerosol precursors.

The organic fraction of the total aged aerosol consisted of hydrocarbon fragments $\left(\mathrm{C}_{x} \mathrm{H}_{y}\right)$, fragments with one oxygen atom $\left(\mathrm{C}_{x} \mathrm{H}_{y} \mathrm{O}\right)$ and fragments with more than one oxygen atom $\left(\mathrm{C}_{x} \mathrm{H}_{y} \mathrm{O}_{z, z>1}\right)$; there was little or no $\mathrm{C}_{x} \mathrm{H}_{y} \mathrm{~N}$ fragments (hydrocarbons with nitrogen) in the total aged particles. The main secondary organic ions detected by the SP-AMS were $\mathrm{CO}_{2}^{+}, \mathrm{CHO}^{+}$and $\mathrm{C}_{2} \mathrm{H}_{3} \mathrm{O}^{+}$. The composition of the organic aerosol was similar in all of the cases: the $\mathrm{C}_{x} \mathrm{H}_{y} \mathrm{O}_{z, z>1}$ group was the largest, followed by $\mathrm{C}_{x} \mathrm{H}_{y}$ and $\mathrm{C}_{x} \mathrm{H}_{y} \mathrm{O}$. The source of the secondary organic aerosol could be either the natural gas or the lubricating oil. However, we are not able to tell the source based on these measurements. The fuel mainly consisted of light hydrocarbons that are unable to form secondary organic aerosol (e.g., Seinfeld and Pandis, 2016, pp. 575). For example, Thiruvengadam et al. (2014) and Eichler et al. (2017) have suspected engine lubricating oil to be responsible for a large portion of engine-emitted particles. Therefore, we believe that also lubricating oil is a potential candidate for the source of secondary aerosol.

The $\mathrm{O}: \mathrm{C}$ ratios of the total aged aerosol measured by SPAMS were between 0.9 and 1.2. The $\mathrm{O}: \mathrm{C}$ ratio of the primary aerosol in the case with the largest concentration was slightly smaller (1.1) than the $\mathrm{O}: \mathrm{C}$ ratio of the total aged aerosol in the same case $\left(\mathrm{M} 2, \mathrm{C} 2,500^{\circ} \mathrm{C}\right)$. In all of the other primary aerosol measurements, the particle mass concentrations in the sample were too low for $\mathrm{O}: \mathrm{C}$ ratio analysis. In comparison with a secondary aerosol emission study on gasoline engines by Karjalainen et al. (2016), the observed $\mathrm{O}: \mathrm{C}$ ratios in the total aged aerosol from the PAM chamber were rather high.

The emission factors or secondary aerosol production factors in different units can be calculated from the presented particle mass concentrations by using the following factors. If a unit factor in $\mathrm{mg} \mathrm{kg}_{\text {fuel }}^{-1}$ is needed, a factor of approximately $22 \mathrm{~m}^{3} \mathrm{~kg}_{\text {fuel }}^{-1}$ can be applied to multiply the particle concentration (calculation, e.g., in Jathar et al., 2017; Gordon et al., 2014b). In order to obtain emission and production factors in units of $\mathrm{kWh}^{-1}$, a factor of $2.7 \mathrm{~m}^{3} \mathrm{kWh}^{-1}$ (mode 1) or $4 \mathrm{~m}^{3} \mathrm{kWh}^{-1}$ (mode 2) can similarly be used. These factors are derived from the fuel composition and engine performance information provided in Sect. 2.1 and 2.2 and the exhaust $\mathrm{CO}_{2}$ concentration. 
Table 1. (a) Particle mass concentrations of primary and total aged particles (SP-AMS), increase of particle mass (\%) in PAM chamber, calculated atmospheric ages simulated by PAM chamber and $\mathrm{O}: \mathrm{C}$ ratios measured by SP-AMS. If no increase in PAM is presented, it is larger than $100000 \%$. (b) The particle mass of species (SP-AMS) in all cases is also presented in the table as well as (c) the concentrations of gaseous emissions in raw exhaust (published already in Lehtoranta et al., 2017). Values have been corrected by the dilution ratio used in the sampling system.

\begin{tabular}{|c|c|c|c|c|c|}
\hline (a) & $\mathrm{M} 1, \mathrm{C} 1,350^{\circ} \mathrm{C}$ & $\mathrm{M} 1, \mathrm{C} 1,400^{\circ} \mathrm{C}$ & $\mathrm{M} 2, \mathrm{C} 1,350^{\circ} \mathrm{C}$ & $\mathrm{M} 2, \mathrm{C} 1,450^{\circ} \mathrm{C}$ & $\mathrm{M} 2, \mathrm{C} 2,500^{\circ} \mathrm{C}$ \\
\hline Primary PM, $\mu \mathrm{g} \mathrm{m}^{-3}, \mathrm{SP}-\mathrm{AMS}$ & 9 & 40 & 31 & 28 & 150 \\
\hline Total aged PM, $\mu \mathrm{g} \mathrm{m}^{-3}$, SP-AMS & 2554 & 2503 & 1210 & 989 & 1093 \\
\hline Increase in PAM \%, SP-AMS & 26800 & 6210 & 3840 & 3440 & 630 \\
\hline Increase in PAM \%, EEPS & 7130 & 1660 & 2680 & 278 & 69 \\
\hline Increase in PAM \%, HRLPI & - & 643 & 22800 & 75 & 4 \\
\hline Atmospheric age, days & 10.0 & 10.7 & 4.6 & 4.7 & 9.3 \\
\hline $\mathrm{O}: \mathrm{C}$ & 1 & 1.1 & 1 & 0.9 & 1.2 \\
\hline \multicolumn{6}{|c|}{ (b) Total aged PM of species, $\mu \mathrm{g} \mathrm{m}^{-3}, \mathrm{SP}-\mathrm{AMS}$} \\
\hline Organic & 944 & 993 & 669 & 430 & 476 \\
\hline Sulfate & 475 & 502 & 228 & 317 & 330 \\
\hline Nitrate & 749 & 641 & 182 & 115 & 143 \\
\hline Ammonium & 372 & 348 & 119 & 121 & 135 \\
\hline \multicolumn{6}{|c|}{ (c) Concentrations of gaseous emissions, ppm } \\
\hline $\mathrm{NO}_{x}$ & 3 & 4 & 3 & 12 & 4 \\
\hline $\mathrm{CO}$ & 14 & 7 & 14 & 8 & 4 \\
\hline Methane & $906 \pm 16$ & $904 \pm 30$ & $2232 \pm 74$ & $2238 \pm 51$ & $1360 \pm 7$ \\
\hline Ethane & 18 & 17 & 68 & 49 & 15 \\
\hline Propane & 1 & 1 & 21 & 6 & 1 \\
\hline Ethene & 0 & 0 & 2 & 0 & 0 \\
\hline
\end{tabular}

Table 2. SOA production factors calculated from the SP-AMS data in this study and in literature (age is $\mathrm{OH}$ exposure $/(1.5 \times$ $10^{6}$ molec $\left.\mathrm{cm}^{-3}\right)$ ). Primary organic aerosol has been subtracted from the total aged organic aerosol.

\begin{tabular}{|c|c|c|c|}
\hline Source & Age & $\mathrm{PF}\left(\mathrm{mg} \mathrm{kg} \mathrm{fuel}_{\text {ful }}^{-1}\right)$ & Reference \\
\hline \multicolumn{4}{|l|}{ NG engine: } \\
\hline $\mathrm{M} 1, \mathrm{C} 1,350^{\circ} \mathrm{C}$ & 10 days & 19 & This study \\
\hline $\mathrm{M} 1, \mathrm{C} 1,400^{\circ} \mathrm{C}$ & 10.7 days & 20 & This study \\
\hline $\mathrm{M} 2, \mathrm{C} 1,350^{\circ} \mathrm{C}$ & 4.6 days & 12 & This study \\
\hline $\mathrm{M} 2, \mathrm{C} 1,450^{\circ} \mathrm{C}$ & 4.7 days & 9 & This study \\
\hline $\mathrm{M} 2, \mathrm{C} 2,500^{\circ} \mathrm{C}$ & 9.3 days & 9 & This study \\
\hline Diesel/biodiesel non-road engine, idling & 1.5 days & $5300-12000$ & Jathar et al. (2017) \\
\hline Diesel/biodiesel non-road engine, $50 \%$ load & 0.8 days & 400-900 & Jathar et al. (2017) \\
\hline Ethanol vehicle, NEDC cycle & $\sim 1-8$ days & $<2^{*}$ & Timonen et al. (2017) \\
\hline Gasoline vehicle, parts of NEDC cycle & $\sim 1-8$ days & $7-155^{*}$ & Karjalainen et al. (2016) \\
\hline Vehicle fleet in highway tunnel & 5.4 days & 350 & Tkacik et al. (2014) \\
\hline Gasoline vehicle, hot start & $3 \mathrm{~h}$ & 13.8 & Gordon et al. (2014a) \\
\hline Gasoline vehicle, cold start & $3 \mathrm{~h}$ & $19-60$ & Gordon et al. (2014a) \\
\hline Gasoline vehicles, idling & $3-6 h$ & $5-90$ & Nordin et al. (2013) \\
\hline Gasoline vehicles, cold start & Unknown & 480 & Nordin et al. (2013) \\
\hline Gasoline vehicle, NEDC cycle & $8 \mathrm{~h}$ & 345 & Platt et al. (2013) \\
\hline Small two-stroke off-road engine & $1-7 \mathrm{~h}$ & $240-1400$ & Gordon et al. (2013) \\
\hline Small four-stroke off-road engine & $1 \mathrm{~h}$ & $100-130$ & Gordon et al. (2013) \\
\hline Diesel vehicle, deactivated catalyst & Unknown & $230-560$ & Chirico et al. (2010) \\
\hline Diesel vehicle, catalyst working & Unknown & $12-20$ & Chirico et al. (2010) \\
\hline
\end{tabular}

* Calculated assuming gasoline density $0.75 \mathrm{kgl}^{-1}$ and consumption $7.9 \mathrm{~L}(100 \mathrm{~km})^{-1}$. 
The production factors of secondary organic aerosol have been calculated and collected in Table 2, in units of $\mathrm{kg}_{\text {fuel }}^{-1}$. To be able to compare the SOA production factors, here primary organic aerosol was subtracted from the total aged organic aerosol. Table 2 also contains SOA production factors of secondary organic aerosol for different diesel and gasoline vehicles obtained from the literature. Although the total aged particulate matter production of the investigated NG engine was much larger than its primary particle emissions, it was smaller than SOA production from in-use diesel and gasoline vehicles in the literature (Tkacik et al., 2014). The SOA formation potential from the NG engine, measured by SPAMS, was similar to that of a diesel vehicle equipped with a catalytic converter or to that of a hot-start gasoline vehicle. On the other hand, the photochemical age that was simulated by a chamber in the different studies varied greatly. This is why the comparison of the SOA production factors should be done very carefully, if at all. The longest atmospheric ages in the literature collected in Table 2 were achieved in our study.

Palm et al. (2016), Tkacik et al. (2014) and Kang et al. (2011) have seen with an oxidation flow reactor - such as the PAM chamber in our experiments - that the highest potential secondary organic aerosol formation takes place at the photochemical age of a few days and starts decreasing after that. For example, in the vehicle fleet emission study in a highway tunnel of Tkacik et al. (2014), the peak secondary aerosol production took place after 4-10 days of equivalent atmospheric oxidation $\left([\mathrm{OH}]=1.5 \times 10^{6} \mathrm{molec} \mathrm{cm}^{-3}\right)$, and larger $\mathrm{OH}$ exposures started to reduce the secondary mass. In our study, the simulated atmospheric, or photochemical, ages in the investigated cases varied between 4.6 and 10.7 days, depending on the external $\mathrm{OH}$ reactivity, which was affected by the concentrations of gaseous emissions (Table 1) entering the PAM chamber and by the relative humidity of the sample. The largest total aged particle concentrations were achieved with the longest atmospheric ages and the lowest particle concentrations were achieved with the shortest atmospheric ages. However, the secondary aerosol formation potential may have also been affected by the engine parameters and not only the achieved photochemical age: the total aged particle concentrations were the highest in engine operation mode 2 (M2).

\subsection{Volatility of primary and secondary particle mass}

The volatility of the particles was studied with a thermodenuder. Mass fraction remaining (MFR) stands for the fraction of the particle mass at a given thermodenuder temperature and the particle mass at room temperature. In Fig. 3, the particle mass fraction remaining has been calculated for two representative cases of primary emissions and four representative cases of total aged particle emissions, selected from among the cases already introduced. Figure 3 only shows data from EEPS, since the curves obtained from HRLPI were similar. Here, the curves have been smoothed by a moving

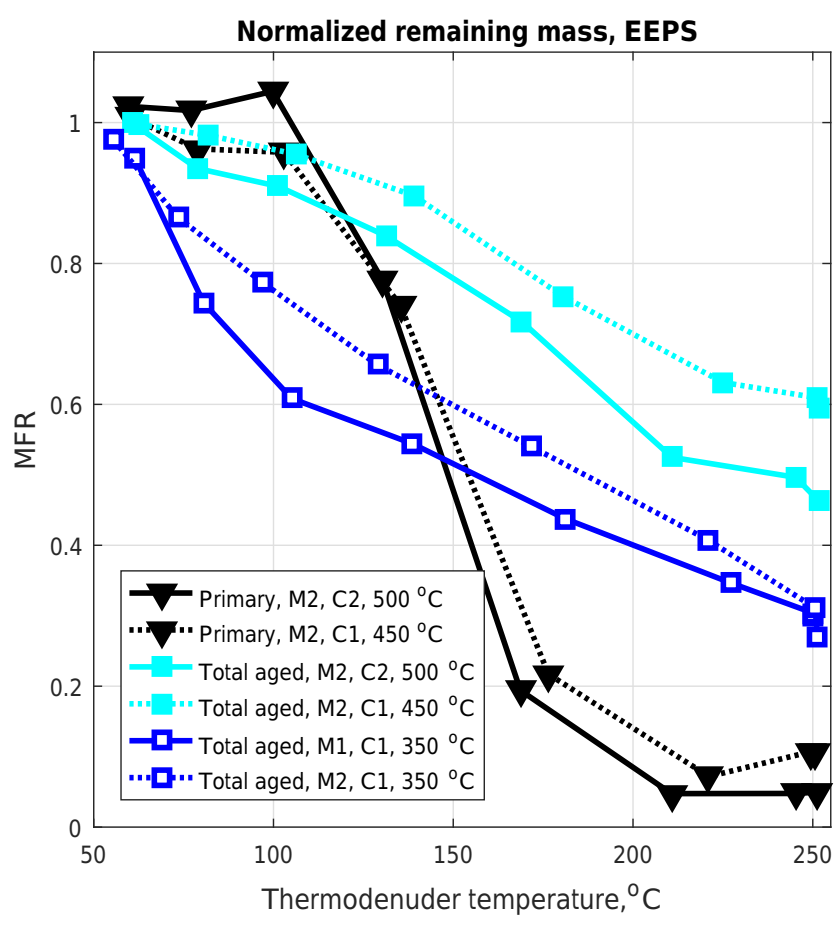

Figure 3. Results of particle volatility measurements. Particle mass fraction remaining (MFR) after the thermodenuder treatment for the exhaust aerosol sample of three different types of particle emissions from the natural gas engine. MFR values were calculated from the size distributions measured by EEPS with unit mass assumption.

average but the original $1 \mathrm{~s}$ resolution figure can be found in the Supplement. For the total aged emissions, the cases with both higher and lower catalyst temperature are presented. For primary particle emissions, only the case with the higher catalyst temperature is presented. This is because an accurate examination of the volatility of primary particles in low catalyst temperatures could not be done, due to the insufficient primary particle mass concentrations for high-quality analysis. In the figure, the "starting point", i.e., the temperature where the mass fraction remaining is one, is $50{ }^{\circ} \mathrm{C}$ and not lower because of the decelerated cooling of the thermodenuder toward the room temperature and related time limitations.

The MFR curves for each type of particles are characteristic, i.e., each particle type can easily be distinguished by their evaporation behavior. To highlight this, the primary particle evaporation is marked with black, and the total aged particle evaporation curves are marked with cyan and blue in Fig. 3 . The volatility of the particles from the natural gas engine clearly changed when the particles were aged. At high catalyst temperature, the primary particles (black triangles in Fig. 3) were more volatile than the total aged particles (cyan squares). Approximately half (46-60\% in EEPS, 43-53\% in HRLPI) of the total aged particle mass remained at a thermodenuder temperature of $250{ }^{\circ} \mathrm{C}$, whereas only $5-10 \%$ (1- 
$4 \%$ in HRLPI) of the primary particle mass remained at that temperature. Also, the catalyst temperature had an impact on the volatility of the total aged particles (blue vs. cyan). An easily evaporable fraction of the total aged particles was formed in the case of a low catalyst temperature, which evaporated below $110^{\circ} \mathrm{C}$. Because of this easily evaporable fraction, the MFR of total aged particles at $250{ }^{\circ} \mathrm{C}$ was $30 \%$ in the low catalyst temperature cases, while in the high catalyst temperature cases the MFR of total aged particles at $250{ }^{\circ} \mathrm{C}$ was $46-60 \%$.

The thermodenuder used in this study has been designed to minimize nanoparticle losses by reducing the residence time (Heikkilä et al., 2009). For example, in this study, the residence time in the heated zone of the thermodenuder was less than $1 \mathrm{~s}$. An et al. (2007) measured the volatility of secondary organic aerosol produced during $\alpha$-pinene photooxidation and observed that only half of the secondary particle mass evaporates in a thermodenuder $\left(100^{\circ} \mathrm{C}\right)$ if the residence times in the heated zone of the thermodenuder are less than a few seconds. With longer residence times, the remaining mass downstream of the thermodenuder decreases to less than $3 \%$. This means that the remaining fraction of particle mass in our study could have been smaller with longer residence times in the thermodenuder. On the other hand, a longer residence time in the thermodenuder would have increased the nanoparticle losses. In this study, with the use of a thermodenuder, we could observe the volatility differences between the different types of particle emissions emitted by a natural gas engine.

In Fig. 4, the remaining mass fractions are plotted for different chemical species of the particles drawn from the SPAMS. In the primary emission case, approximately one-third of the particle mass - consisting mainly of organics - remained at TD temperature of $250^{\circ} \mathrm{C}$. The low concentrations and particle size below the detection limit of SP-AMS degrade the analysis in the case $\mathrm{M} 2, \mathrm{C} 1,450^{\circ} \mathrm{C}$, which was seen as a fluctuating signal. About $25 \%$ of the total aged particle mass in the high catalyst temperature cases and less than $10 \%$ of the total aged particle mass in low catalyst temperature cases remained at $250^{\circ} \mathrm{C}$, according to SP-AMS. The remaining particle matter consisted of organics, sulfate and ammonium, in this order.

The composition information reveals that the highvolatility fraction of the total aged particles in the low temperature catalyst cases consisted of nitrates, possibly of ammonium nitrate and high-volatility organics. The primary particle sulfate evaporated at thermodenuder temperatures between 100 and $170^{\circ} \mathrm{C}$, and the total aged particle sulfate evaporated more gradually above $120^{\circ} \mathrm{C}$. In all types of particles, the evaporation of organics was steady and gradual below $200^{\circ} \mathrm{C}$, indicating various organic compounds with different evaporation temperatures. Above $200^{\circ} \mathrm{C}$, the evaporation of organics decreased. This combined SP-AMS and EEPS/HRLPI derived thermodenuder temperature ramp information can be used in future measurements for particle
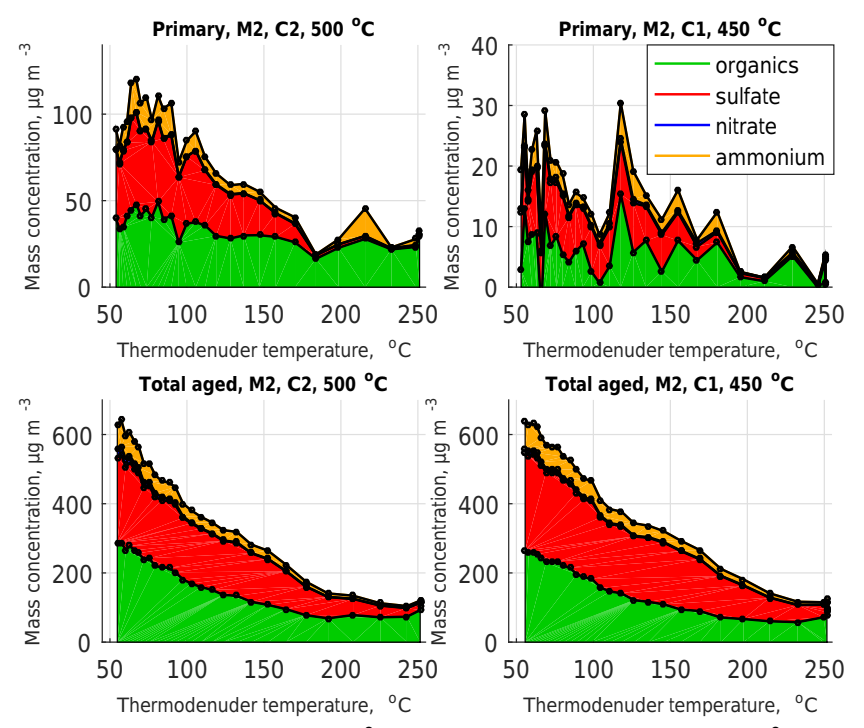

Total aged, M2, C1, $450{ }^{\circ} \mathrm{C}$
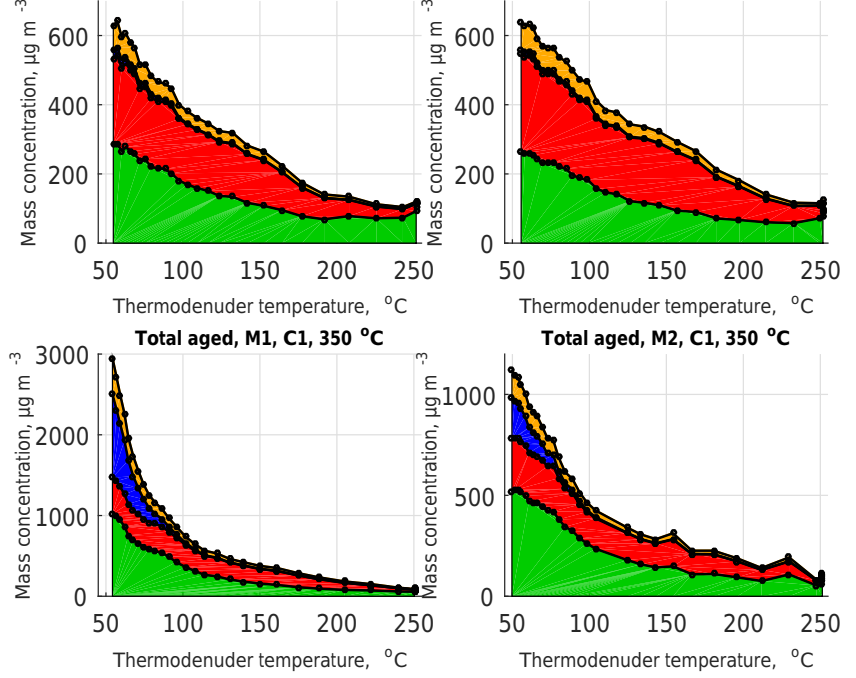

Figure 4. Concentration of different chemical compounds of particles remaining after the thermodenuder treatment conducted for the exhaust aerosol. The mass concentrations were measured using the SP-AMS at different thermodenuder temperatures and corrected by the dilution ratio used in the sampling system.

composition analysis: the evaporation temperature of the particles can give valuable information about the composition of the particles also without access to SP-AMS.

The temperatures at which $50 \%$ of the volatile fraction of the chemical compounds of the particles were remaining are collected in Table 3. The case "primary, $\mathrm{M} 2, \mathrm{C} 1,450^{\circ} \mathrm{C}$ " had particle mass concentrations that were too low (see Fig. 4) for this kind of examination. The evaporation temperatures of sulfate and nitrate were the highest and the lowest, respectively, in all of the analyzed cases (all catalyst temperatures; primary and total aged particles). Similarly to Huffman et al. (2009), who measured ambient aerosol volatility in megacities with a thermodenuder and an SP-AMS, we found that nitrate had the highest volatility and sulfate had the lowest.

Robinson et al. (2007) and Huffman et al. (2009) proposed that all organic aerosol should be considered semivolatile. Our results on primary and PAM-chamber-generated organic aerosols point in that direction as well. The evaporation temperature of the volatile fraction $\left(T_{\text {volatile, } 50 \%}\right)$ of organic matter remained between the $T_{\text {volatile, }} 50 \%$ of nitrate and sulfate in all cases. Also, a significant fraction of the mass concentration of the organic matter did not evaporate. More exact 
Table 3. The temperatures where $50 \%$ of the volatile fraction of species has evaporated.

\begin{tabular}{lrrrrrr}
\hline $\begin{array}{l}T_{\text {volatile, }} 0 \% \\
\left({ }^{\circ} \mathrm{C}\right)\end{array}$ & $\begin{array}{r}\text { Primary } \\
\mathrm{M} 2, \mathrm{C} 2,50{ }^{\circ} \mathrm{C}\end{array}$ & $\begin{array}{r}\text { M2, } \mathrm{C} 1,450{ }^{\circ} \mathrm{C} \\
\mathrm{M} 2, \mathrm{C} 2,500^{\circ} \mathrm{C}\end{array}$ & $\begin{array}{r}\text { Total aged } \\
\mathrm{M} 2, \mathrm{C} 1,450^{\circ} \mathrm{C}\end{array}$ & $\begin{array}{r}\text { Total aged } \\
\mathrm{M} 1, \mathrm{C} 1,350^{\circ} \mathrm{C}\end{array}$ & $\begin{array}{r}\text { Total aged } \\
\mathrm{M} 2, \mathrm{C} 1,350^{\circ} \mathrm{C}\end{array}$ \\
\hline Organics & 115 & - & 99 & 104 & 87 & 93 \\
Sulfate & 125 & - & 152 & 168 & 120 & 147 \\
Nitrate & 72 & - & 80 & 84 & 65 & 65 \\
Ammonium & 104 & - & 97 & 112 & 70 & 79 \\
\hline
\end{tabular}

specifications of the volatility cannot be given, but there is room left for speculation if part of the organic matter in secondary particles is semi-volatile (SV-SOA) or low volatility (LV-SOA) secondary organic aerosol (Murphy et al., 2014).

The ammonium in total aged particles evaporated at higher thermodenuder temperatures when the catalyst temperature was high. The theory that the sulfate-nitrate trade-off phenomenon that determines the formation of nitrates is ammonium bound is supported by the evaporation temperatures of ammonium. Ammonium evaporated at approximately $20^{\circ} \mathrm{C}$ higher thermodenuder temperatures in the high catalyst temperature cases (Table 3); thus, its evaporation temperature was closer to the evaporation temperature of sulfate when the sulfate concentration of the particles was larger. By contrast, in the low catalyst temperature cases where the nitrate concentration was higher, the evaporation temperature of ammonium was closer to that of nitrate.

The nitrate concentrations measured during the thermodenuder temperature ramp (Fig. 4) in low thermodenuder temperatures differed from the nitrate concentrations that were measured without a thermodenuder (Fig. 2a and b) in total aged particles. A possible explanation is that a long time is needed for the nitrate concentration to stabilize. In our measurement protocol, we waited $10-15 \mathrm{~min}$ after switching the PAM UV lights on, followed by a 10 min steady-state measurement with the aerosol instruments. After this, a thermodenuder ramp was started, which took approximately $45 \mathrm{~min}$. Based on the results, the $10-15$ min wait was insufficient if accurate nitrate concentrations were desired. Therefore, the chemical compound measurements performed at low thermodenuder temperature can give a truer picture of the secondary aerosol formation than the measurements presented in Fig. 2. The change in concentrations between the steadystate measurements and the thermodenuder ramp measurements was the largest for nitrate, but the concentrations of other compounds also differed slightly from each other. Because the nitrate concentrations were found to be the slowest to stabilize and the most sensitive to changes in the system, such as to changes in temperature, special attention should be given to measurements of nitrate, especially when a PAM chamber is being used. We note that because nitrate formation is limited by ammonium, the slow stabilization is probably related to ammonia.
According to our thermodenuder temperature ramp experiments, the catalyst temperature affected the total aged particle composition. With a decreasing catalyst temperature, the mass concentration and fraction of sulfate in total aged particles decreased (Fig. 4, Table 1). This was expected: at lower catalyst temperatures the oxidation of $\mathrm{SO}_{2}$ to $\mathrm{SO}_{3}$ decreases and less sulfuric acid (sulfates) can form (Arnold et al., 2012). The mass concentration of nitrate in secondary particles increased as the catalyst temperature decreased. This could not be explained by catalyst performance improvement: gaseous $\mathrm{NO}_{x}$ levels remained similar at all catalyst temperatures or rose as catalyst temperature increased (see Lehtoranta et al., 2017). Because ammonia concentrations after catalyst were low, below $2 \mathrm{ppm}$ in all cases, the effect of catalyst temperature on ammonia emission could not be measured. However, ammonium concentrations measured by SP-AMS correlated rather well with nitrate concentrations. Therefore, we suggest that ammonium increase was related to the nitrate increase. Also, the sulfate concentrations could partly explain the behavior of the nitrate concentrations. If enough gaseous sulfuric acid is available, ammonium sulfate forms, and if not, more ammonium nitrate can form instead. A similar behavior of nitrate and sulfate trade-off has been measured by Ntziachristos et al. (2016) for two different marine fuels, namely heavy fuel oil (HFO) and light fuel oil (LFO).

\subsection{Differences between instruments and mass size distributions}

Slightly unexpectedly, the total aged particle mass measured by SP-AMS was 2-4 times larger than the total mass measured by EEPS and 1-3 times larger than that measured by HRLPI (Fig. 2). There could be several reasons for this. In EEPS and HRLPI, unit density and spherical particles were assumed in the mass calculations. Natural gas engine primary particles have a density of $0.85 \mathrm{~g} \mathrm{~cm}^{-3}$ (Bullock and Olfert, 2014), but the densities of natural gas engine secondary particles can be larger than the unit density. For example, the density of ammonium nitrate, ammonium sulfate and sulfuric acid is approximately $1.5,1.5$ and $1.8 \mathrm{~g} \mathrm{~m}^{-3}$, respectively (Clegg and Wexler, 2011). Particle density does not completely explain the difference in instrument readings. Also, the collection efficiency (CE) estimation used in the SP-AMS calculation is probably not the reason for the differences be- 

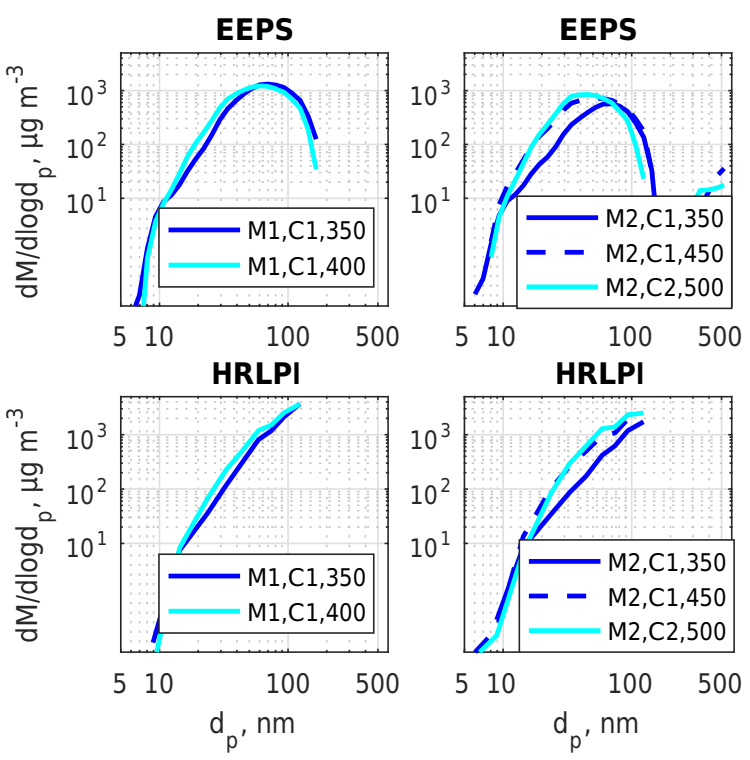

Figure 5. Particle mass size distributions measured by EEPS and HRLPI and corrected by the dilution ratios. Cases M1, C1 are on the left, and cases M2, C1 and M2, C2 are on the right. Cyan curves stand for the higher catalyst temperatures and blue for the lower ones.

tween the instrument results in this study. Evaluation of the CE following the procedure of Middlebrook et al. (2012) revealed that $C E$ equal to 0.45 was the correct value for the studied total aged particles in the cases in Fig. 1.

However, the detection efficiency and size range varied among the aerosol instruments (EEPS $5.6-560 \mathrm{~nm}$, HRLPI $\sim 5-200 \mathrm{~nm}$, SP-AMS 30-1000 nm) and can explain the differences in results; HRLPI can detect a larger fraction of the primary particles than SP-AMS because of the more suitable size range of the instrument and, correspondingly, SP-AMS can detect a larger fraction of the total aged particles formed in the PAM chamber because of its more suitable size range. Also, particle losses may play a role in the differences between instruments; particle losses in the PAM chamber were larger in the HRLPI size range than in the SP-AMS size range. Nevertheless, most probably, the largest role was played by the differences in instrument size ranges.

Mass size distributions of the total aged aerosol, measured with EEPS and HRLPI, are plotted in Fig. 5. HRLPI suggests that a part of the particle mass lies above the instrument size range, which was confirmed by SP-AMS mass size distributions in Fig. 6. According to SP-AMS, the mass size distributions of total aged particles were bimodal, with the size of the larger mode being $480-840 \mathrm{~nm}$ and the smaller being $150-200 \mathrm{~nm}$. The mode with smaller particle size was dominated by organics. Although the mass concentration of the total aged particles was better recorded by SP-AMS, a portion of the particles on the smallest particle sizes was missed

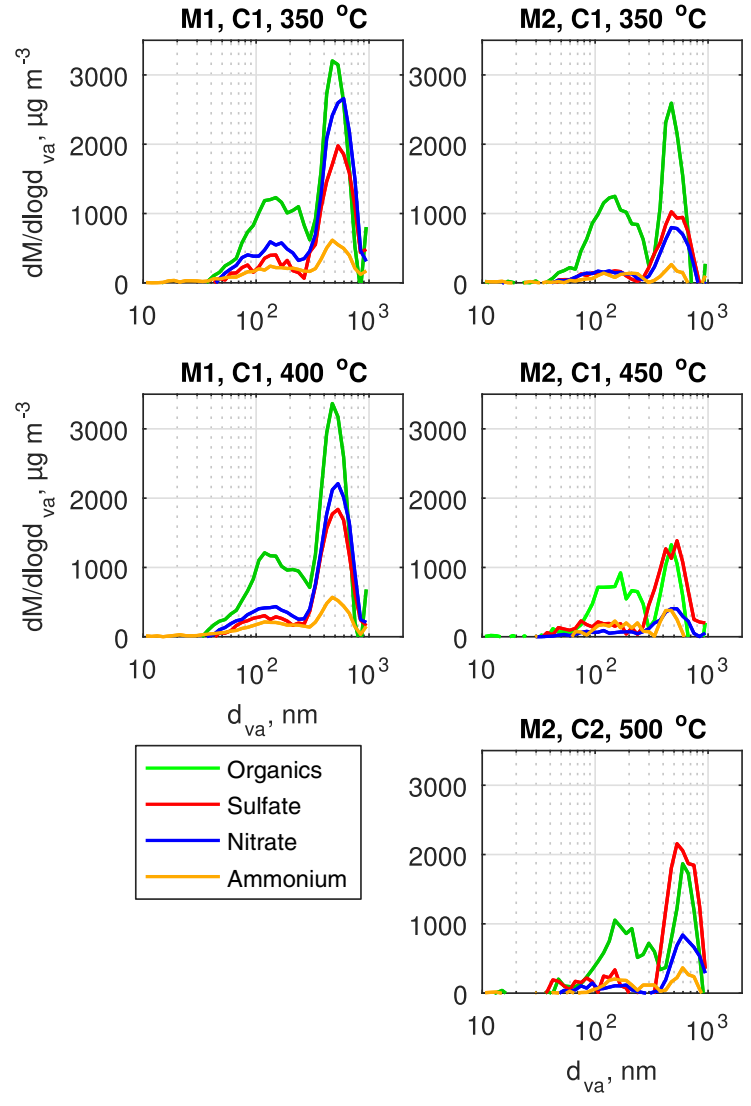

Figure 6. Component-wise particle mass size distributions measured by SP-AMS and corrected by the dilution ratios.

due to the lower limit of SP-AMS size range at $30-50 \mathrm{~nm}$. The best overall picture is therefore gained with a combination of SP-AMS and HRLPI. See the Supplement for a comparison of the size distributions measured by different instruments in the same figure. The two instruments that measure the aerodynamic diameter of the particles (HRLPI and SPAMS) compare quite well with each other in the size range $47-124 \mathrm{~nm}$.

We can also see a difference between the EEPS and HRLPI mass size distributions. The difference is probably due to the inversion of EEPS, which forces the size distributions to follow a log-normal shape. EEPS also underestimated the mass of particles with diameter above $200 \mathrm{~nm}$ (see the Supplement). The different measurement principles of the instruments must also be kept in mind. EEPS measures the mobility size and HRLPI measures the aerodynamic size of the particles.

\subsection{PAM artifacts and losses}

The so-called smog chambers are an established method of measuring SOA formation. An oxidation flow chamber such as PAM provides some advantages in comparison to smog chambers, such as a higher degree of oxidation, smaller phys- 
ical size and a short residence time, which allows measurements with higher time resolution. Smog chamber walls may also cause large wall losses and influence the chemistry in the chamber (Bruns et al., 2015). On the other hand, smog chambers may simulate the atmospheric oxidation of organic precursors better than oxidation flow chambers due to their more tropospheric oxidant concentrations and longer residence times (Lambe et al., 2011).

The PAM method has been designed to produce the maximum potential aerosol mass from precursor gases (Kang et al., 2007). In that stage, the oxidation products of precursors have condensed into the particle phase and formed secondary aerosol. However, because the oxidant concentrations are unrealistically high in PAM, the UV-light intensity used is non-tropospheric and the residence times are much shorter than in the atmosphere (e.g., Simonen et al., 2017), precursor oxidation products also have other possible fates; they can be oxidized too far and form non-condensable oxidation products before condensation (accelerated chemistry) and they can exit the reactor before the condensation occurs. Also, precursor oxidation products can be lost on the PAM walls although the losses on the walls are minimized by the chamber design (Lambe et al., 2011). The fates other than condensing on particle phase are viewed here as PAM artifacts and losses.

The losses of condensable organic oxidation products and artifact effects of the accelerated chemistry in the PAM have been evaluated following the method of Palm et al. (2016) for the cases in Fig. 2. HRLPI number size distributions were used to calculate the condensation sink needed in the loss calculation. A molar mass of $200 \mathrm{~g} \mathrm{~mol}^{-1}$, a diffusion coefficient of $7 \times 10^{-6} \mathrm{~m}^{2} \mathrm{~s}^{-1}$ (Tang et al., 2015) and a rate constant for reaction with $\mathrm{OH}$ of $1 \times 10^{-11}$ (Ziemann and Atkinson, 2012) were applied. For sticking coefficient selection $\alpha=1$ (assumed by Palm et al., 2016), the fraction of oxidation products that condensed into the particle phase was $0.94 \pm 0.03$, but for $\alpha=0.1$ the fraction of oxidation products that condensed into the particle phase was $0.64 \pm 0.15$.

The losses of sulfuric acid were also calculated in the same way. A diffusion coefficient of $1 \times 10^{-5}$ (Hanson and Eisele, 2000), $\alpha$ of 0.65 (Pöschl et al., 1998) and molar mass of $98.079 \mathrm{~g} \mathrm{~mol}^{-1}$ were used for sulfuric acid. The fraction of sulfuric acid that condensed into the particle phase was $0.98 \pm 0.01$. According to Lambe et al. (2011), $\mathrm{SO}_{2}$ losses in the PAM are negligible. It can be concluded that the effect of precursor losses and artifacts in the PAM was not substantial in our measurements. The measurement of ammonium nitrate and ammonium sulfate is difficult because ammonia sticks on the walls of sampling systems and instruments (Suarez-Bertoa et al., 2015; Heeb et al., 2012, 2008), which may result in wall losses or an artifact on subsequent measurements. The penetration of ammonia could not be calculated, but the measured ammonium concentrations varied clearly from one case to another, implicating that the source of the ammonia was indeed the exhaust line instead of, e.g., the walls of the PAM. However, longer times for the stabilization of the SP-AMS concentration would have been advantageous for the reliability of ammonium and, as a consequence, nitrate particle formation.

Karjalainen et al. (2016) and Timonen et al. (2017) estimated the effect of particle losses in a similar PAM chamber to be small. The particle losses measured by Karjalainen et al. (2016) depend on particle size and are below $10 \%$ at the particle sizes with most particle mass. An exact calculation of the particle losses in the PAM chamber is not possible because the particle size and number increase while the aerosol sample flows through the chamber. An estimation for the particle mass losses in the chamber can be given, calculated using the average of HRLPI particle number size distributions before and after the chamber (similarly to the precursor-loss calculation by Palm et al., 2016) and the PAM particle loss curve. The particle mass loss according to this examination was $20.3 \pm 3.7 \%$. Most probably, however, the actual particle mass losses in the chamber were smaller because majority of the mass actually was located at larger particle sizes that HRLPI is unable to measure, where particle losses are smaller.

No loss corrections were done based on these calculations on the results presented in this article. If corrections had been made, the presented secondary aerosol productions and production factors would be slightly higher (less than $10 \%$ ) in Figs. 2 and 4-6, and in Tables 1 and 2.

\section{Conclusions}

Natural gas engines emit very little particle mass, which can make them less harmful to human health than corresponding gasoline-, diesel- or marine-fuel-oil-fueled engines. However, secondary aerosol formation also increases human exposure to aerosol particles. When natural gas engines become more common in traffic and energy production, their potential for secondary particle formation will become more important and an even more relevant object for research. Therefore, it is important to study the potential reduction of the total aerosol particle mass and related health and climate effects when shifting from liquid fuels to natural gas or biogas in combustion engines is important.

In this study, a retro-fitted natural gas engine equipped with exhaust after-treatment was studied in a laboratory in an engine test bench, using steady-state engine operation modes, i.e., constant engine speed and torque. The secondary aerosol formation was studied using a (PAM) chamber. Estimates for the atmospheric ages achieved by the PAM chamber were 4.6-10.7 days. In this study, the secondary aerosol mass potential of natural gas emission was measured to be at a small or medium level but was well measurable. Compared to the primary particle mass emissions from the same engine, the secondary aerosol formation potential was substantial approximately $1-2$ orders of magnitude higher than the pri- 
mary aerosol mass. However, the very small primary particle masses in some of the observed engine and catalyst operation modes complicated this comparison. To give a rough estimate to the quantity of the NG engine exhaust's SOA formation potential, it was on the same level as or lower than the SOA formation potential of a diesel vehicle equipped with an oxidation catalyst or that of warm (hot-start) gasoline vehicles. However, the photochemical age that was produced by the PAM chamber in our study was longer (several days) than the photochemical ages achieved in the previous studies (several hours). Therefore, the SOA formation potential must not be directly compared. Also, despite the attempts to model PAM-related losses and artifacts, and to estimate particle losses in PAM, the measurements performed with PAM still involve uncertainties.

The total aged aerosol, i.e., the combined primary and secondary aerosol (downstream of a PAM chamber) of the NG engine, consisted of organic matter, nitrate, sulfate and ammonium, roughly in this order. It was found that aging of the exhaust generates low-volatility organics. However, the composition of the secondary aerosol was, for the most part, inorganic; the fraction of organic matter in the secondary particles varied between 37 and $56 \%$.

Exhaust after-treatment was found to have an effect on the secondary aerosol composition. High catalyst temperature promoted the formation of sulfate particles in total aged aerosol, whereas low catalyst temperatures promoted nitrate formation. Because the amount of $\mathrm{NO}_{x}$ emissions was reduced at the lower catalyst temperatures, it was concluded that the formation of nitrate in particles (total aged) depended on the ammonia concentration and sulfate particle formation rather than the $\mathrm{NO}_{x}$ emissions. Sulfate and nitrate are likely to exist in the forms of ammonium sulfate and ammonium nitrate. Therefore, what limits the nitrate mass in particles is most likely the availability of ammonia which is more related to the exhaust after-treatment than fuel or combustion processes.

The total aged nanoparticles formed from the natural gas exhaust were found to be less volatile than the primary particles. This can affect their lifetime in the atmosphere and therefore their impact on the radiative balance of the atmosphere or their potential to act as cloud nuclei. A higher catalyst temperature impacts the total aged particles by decreasing their volatility or by decreasing their volatile fraction.

In our study, only one constant PAM UV-light voltage could be used. With improved instrumentation, a broader variation in light intensity could be achieved, thus improving our knowledge regarding the evolution of the secondary aerosol. Also, because natural gas is not the only widely used gaseous fuel, the secondary aerosol formation potential of a more extensive fuel selection would be interesting to study. The role of lubricating oil is not known yet either - studies performed at different natural gas combustion sites and with various lubricating oils would reveal its significance to secondary aerosol formation.
Code and data availability. The data and code of this study are available from the authors upon request.

\section{The Supplement related to this article is available online at https://doi.org/10.5194/acp-17-8739-2017-supplement.}

Competing interests. The authors declare that they have no conflict of interest.

Acknowledgements. This study was funded by Tekes, the Finnish Funding Agency for Innovation, Neste, AGCO Power, Wärtsilä, Dinex Ecocat, Dekati, Suomi Analytics and Viking Line. Jenni Alanen acknowledges Gasum's gas funding for financial support. Pauli Simonen acknowledges the TUT Graduate School for its funding. Oskari Kangasniemi acknowledges the Nessling Foundation for its funding. Topi Rönkkö acknowledges the financial support from the Academy of Finland (ELTRAN project, grant no. 293437).

Edited by: Rob MacKenzie

Reviewed by: two anonymous referees

\section{References}

Alanen, J., Saukko, E., Lehtoranta, K., Murtonen, T., Timonen, H., Hillamo, R., Karjalainen, P., Kuuluvainen, H., Harra, J., Keskinen, J., and Rönkkö, T.: The formation and physical properties of the particle emissions from a natural gas engine, Fuel, 162, 155-161, https://doi.org/10.1016/j.fuel.2015.09.003, 2015.

An, W. J., Pathak, R. K., Lee, B. H., and Pandis, S. N.: Aerosol volatility measurement using an improved thermodenuder: application to secondary organic aerosol, J. Aerosol Sci., 38, 305-314, https://doi.org/10.1016/j.jaerosci.2006.12.002, 2007.

Anderson, M., Salo, K., and Fridell, E.: Particle- and gaseous emissions from an LNG powered ship, Environ. Sci. Technol., 49, 12568-12575, https://doi.org/10.1021/acs.est.5b02678, 2015.

Arffman, A., Yli-Ojanperä, J., Kalliokoski, J., Harra, J., Pirjola, L., Karjalainen, P., Rönkkö, T., and Keskinen, J.: High-resolution low-pressure cascade impactor, J. Aerosol Sci., 78, 97-109, https://doi.org/10.1016/j.jaerosci.2014.08.006, 2014

Arnold, F., Pirjola, L., Rönkkö, T., Reichl, U., Schlager, H., Lähde, T., Heikkilä, J., and Keskinen, J.: First online measurements of sulfuric acid gas in modern heavy-duty diesel engine exhaust: implications for nanoparticle formation, Environ. Sci. Technol., 46, 11227-11234, https://doi.org/10.1021/es302432s, 2012.

Atkinson, R., Baulch, D., Cox, R., Crowley, J., Hampson, R., Hynes, R., Jenkin, M., Kerr, J., Rossi, M., and Troe, J.: IUPAC Subcommittee for gas kinetic data evaluation, Evaluated kinetic data, available at: http://www.iupac-kinetic.ch.cam.ac.uk (last access: 13 December 2016), 2007.

Bahreini, R., Middlebrook, A. M., Brock, C. A., Gouw, J. A. D., Mckeen, S. A., Williams, L. R., Daumit, K. E., Lambe, A. T., 
Massoli, P., Canagaratna, M. R., Ahmadov, R., Carrasquillo, A. J., Cross, E. S., Ervens, B., Holloway, J. S., Hunter, J. F., Onasch, T. B., Pollack, I. B., Roberts, J. M., Ryerson, T. B., Warneke, C., Davidovits, P., Worsnop, D. R., and Kroll, J. H.: Mass spectral analysis of organic aerosol formed downwind of the deepwater horizon oil spill: field studies and laboratory confirmations, Environ. Sci. Technol., 46, 8025-8034, https://doi.org/10.1126/science.1200320, 2012.

Bielaczyc, P., Woodburn, J., and Szczotka, A.: An assessment of regulated emissions and $\mathrm{CO}_{2}$ emissions from a European light-duty CNG-fueled vehicle in the context of Euro 6 emissions regulations, Appl. Energ., 117, 134-141, https://doi.org/10.1016/j.apenergy.2013.12.003, 2014.

Bruns, E. A., El Haddad, I., Keller, A., Klein, F., Kumar, N. K., Pieber, S. M., Corbin, J. C., Slowik, J. G., Brune, W. H., Baltensperger, U., and Prévôt, A. S. H.: Inter-comparison of laboratory smog chamber and flow reactor systems on organic aerosol yield and composition, Atmos. Meas. Tech., 8, 23152332, https://doi.org/10.5194/amt-8-2315-2015, 2015.

Bullock, D. S. and Olfert, J. S.: Size, volatility, and effective density of particulate emissions from a homogeneous charge compression ignition engine using compressed natural gas, J. Aerosol Sci., 75, 1-8, https://doi.org/10.1016/j.jaerosci.2014.04.005, 2014.

Burkholder, J. B., Sander, S. P., Abbatt, J., Barker, J. R., Huie, R. E., Kolb, C. E., Kurylo, M. J., Orkin, V. L., Wilmouth, D. M., and H., W. P.: Chemical Kinetics and Photochemical Data for Use in Atmospheric Studies, Evaluation No. 18, JPL Publication 15-10, Jet Propulsion Laboratory, Pasadena, available at: http://jpldataeval.jpl.nasa.gov (last access: 13 December 2016), 2015.

Chirico, R., DeCarlo, P. F., Heringa, M. F., Tritscher, T., Richter, R., Prévôt, A. S. H., Dommen, J., Weingartner, E., Wehrle, G., Gysel, M., Laborde, M., and Baltensperger, U.: Impact of aftertreatment devices on primary emissions and secondary organic aerosol formation potential from in-use diesel vehicles: results from smog chamber experiments, Atmos. Chem. Phys., 10, 11545-11563, https://doi.org/10.5194/acp-10-115452010, 2010.

Clegg, S. L. and Wexler, A. S.: Densities and apparent molar volumes of atmospherically important electrolyte solutions. 2 . The systems $\mathrm{H}^{+}-\mathrm{HSO}_{4}^{-}-\mathrm{SO}_{4}^{2-}-\mathrm{H}_{2} \mathrm{O}$ from 0 to $3 \mathrm{~mol} \mathrm{~kg}^{-1}$ as a function of temperature and $\mathrm{H}^{+}-\mathrm{NH}_{4}^{+}-\mathrm{HSO}_{4}^{-}-\mathrm{SO}_{4}^{2-}-\mathrm{H}_{2} \mathrm{O}$ from 0 to $6 \mathrm{~mol} \mathrm{~kg}^{-1}$ at $25^{\circ} \mathrm{C}$ using a pitzer ion interaction model, and $\mathrm{NH}_{4} \mathrm{HSO}_{4}-\mathrm{H}_{2} \mathrm{O}$ and $\left.\left(\mathrm{NH}_{4}\right)_{3}\right) \mathrm{H}\left(\mathrm{SO}_{4}\right)_{2}-\mathrm{H}_{2} \mathrm{O}$ over entire concentration range, J. Phys. Chem.-US, 115, 3461-3474, https://doi.org/10.1021/jp1089933, 2011.

Damian, V., Sandu, A., Damian, M., Potra, F., and Carmichael, G. R.: The kinetic preprocessor KPP-a software environment for solving chemical kinetics, Comput. Chem. Engin., 26, 1567-1579, https://doi.org/10.1016/S00981354(02)00128-X, 2002.

Dockery, D. and Pope III, A.: Acute respiratory effects of particulate air pollution, Annu. Rev. Publ. Health, 15, 107-132, 1994.

Eichler, P., Muller, M., Rohmann, C., Stengel, B., Orasche, J., Zimmermann, R., and Wisthaler, A.: Lubricating oil as a major constituent of ship exhaust particles, Environ. Sci. Tech. Let., 4, 54$58,2017$.
Gentner, D. R., Jathar, S. H., Gordon, T. D., Bahreini, R., Day, D. A., Haddad, I. E., Hayes, P. L., Pieber, S. M., Platt, S. M., Gouw, J. D., Goldstein, A. H., Harley, R. A., Jimenez, J. L., Prévôt, A. S. H., and Robinson, A. L.: Review of urban secondary organic aerosol formation from gasoline and diesel motor vehicle emissions, Environ. Sci. Technol., 51, 1074-1096, https://doi.org/10.1021/acs.est.6b04509, 2017.

Gordon, T. D., Tkacik, D. S., Presto, A. A., Zhang, M., Jathar, S. H., Nguyen, N. T., Massetti, J., Truong, T., Cicero-Fernandez, P., Maddox, C., Rieger, P., Chattopadhyay, S., Maldonado, H., Maricq, M. M., and Robinson, A. L.: Primary gas- and particlephase emissions and secondary organic aerosol production from gasoline and diesel off-road engines, Environ. Sci. Technol., 47, 14137-14146, https://doi.org/10.1021/es403556e, 2013.

Gordon, T. D., Presto, A. A., May, A. A., Nguyen, N. T., Lipsky, E. M., Donahue, N. M., Gutierrez, A., Zhang, M., Maddox, C., Rieger, P., Chattopadhyay, S., Maldonado, H., Maricq, M. M., and Robinson, A. L.: Secondary organic aerosol formation exceeds primary particulate matter emissions for lightduty gasoline vehicles, Atmos. Chem. Phys., 14, 4661-4678, https://doi.org/10.5194/acp-14-4661-2014, 2014a.

Gordon, T. D., Presto, A. A., Nguyen, N. T., Robertson, W. H., Na, K., Sahay, K. N., Zhang, M., Maddox, C., Rieger, P., Chattopadhyay, S., Maldonado, H., Maricq, M. M., and Robinson, A. L.: Secondary organic aerosol production from diesel vehicle exhaust: impact of aftertreatment, fuel chemistry and driving cycle, Atmos. Chem. Phys., 14, 4643-4659, https://doi.org/10.5194/acp-14-4643-2014, 2014b.

Goyal, P. and Sidhartha: Present scenario of air quality in Delhi: a case study of CNG implementation, Atmos. Environ., 37, 54235431, https://doi.org/10.1016/j.atmosenv.2003.09.005, 2003.

Graves, B., Olfert, J., Patychuk, B., Dastanpour, R., and Rogak, S.: Characterization of particulate matter morphology and volatility from a compression-ignition natural-gas direct-injection engine, Aerosol Sci. Tech., 49, 589-598, https://doi.org/10.1080/02786826.2015.1050482, 2015.

Hallquist, M., Wenger, J. C., Baltensperger, U., Rudich, Y., Simpson, D., Claeys, M., Dommen, J., Donahue, N. M., George, C., Goldstein, A. H., Hamilton, J. F., Herrmann, H., Hoffmann, T., Iinuma, Y., Jang, M., Jenkin, M. E., Jimenez, J. L., Kiendler-Scharr, A., Maenhaut, W., McFiggans, G., Mentel, Th. F., Monod, A., Prévôt, A. S. H., Seinfeld, J. H., Surratt, J. D., Szmigielski, R., and Wildt, J.: The formation, properties and impact of secondary organic aerosol: current and emerging issues, Atmos. Chem. Phys., 9, 5155-5236, https://doi.org/10.5194/acp9-5155-2009, 2009.

Hallquist, Å. M., Jerksjö, M., Fallgren, H., Westerlund, J., and Sjödin, Å.: Particle and gaseous emissions from individual diesel and CNG buses, Atmos. Chem. Phys., 13, 5337-5350, https://doi.org/10.5194/acp-13-5337-2013, 2013.

Hanson, D. R. and Eisele, F.: Diffusion of $\mathrm{H}_{2} \mathrm{SO}_{4}$ in humidified nitrogen: hydrated $\mathrm{H}_{2} \mathrm{SO}_{4}$, J. Phys. Chem.-US, 104, 1715-1719, 2000.

Heeb, N. V., Saxer, C. J., Forss, A.-m., and Brühlmann, S.: Trends of $\mathrm{NO}-, \mathrm{NO}_{2-}$, and $\mathrm{NH}_{3}$-emissions from gasoline-fueled Euro3- to Euro-4-passenger cars, Atmos. Environ., 42, 2543-2554, https://doi.org/10.1016/j.atmosenv.2007.12.008, 2008.

Heeb, N. V., Haag, R., Seiler, C., Schmid, P., Zennegg, M., Wichser, A., Ulrich, A., Honegger, P., Zeyer, K., Emmeneg- 
ger, L., Zimmerli, Y., Czerwinski, J., Kasper, M., and Mayer, A.: Effects of a combined Diesel Particle Filter-DeNOx System (DPN) on reactive nitrogen compounds emissions: a parameter study, Environ. Sci. Technol., 46, 13317-13325, 2012.

Heikkilä, J., Rönkkö, T., Lähde, T., Lemmetty, M., Arffman, A., Virtanen, A., Keskinen, J., Pirjola, L., and Rothe, D.: Effect of open channel filter on particle emissions of modern diesel engine, J. Air Waste Manage., 59, 1148-1154, https://doi.org/10.3155/1047-3289.59.10.1148, 2009.

Huang, R. J., Zhang, Y., Bozzetti, C., Ho, K. F., Cao, J. J., Han, Y., Daellenbach, K. R., Slowik, J. G., Platt, S. M., Canonaco, F., Zotter, P., Wolf, R., Pieber, S. M., Bruns, E. A., Crippa, M., Ciarelli, G., Piazzalunga, A., Schwikowski, M., Abbaszade, G., Schnelle-Kreis, J., Zimmermann, R., An, Z., Szidat, S., Baltensperger, U., El Haddad, I., and Prévôt, A. S.: High secondary aerosol contribution to particulate pollution during haze events in China, Nature, 514, 218-222, https://doi.org/10.1038/nature13774, 2014.

Huffman, J. A., Docherty, K. S., Aiken, A. C., Cubison, M. J., Ulbrich, I. M., DeCarlo, P. F., Sueper, D., Jayne, J. T., Worsnop, D. R., Ziemann, P. J., and Jimenez, J. L.: Chemically-resolved aerosol volatility measurements from two megacity field studies, Atmos. Chem. Phys., 9, 7161-7182, https://doi.org/10.5194/acp9-7161-2009, 2009.

Jathar, S. H., Miracolo, M. A., Tkacik, D. S., Donahue, N. M., Adams, P. J., and Robinson, A. L.: Secondary organic aerosol formation from photo-oxidation of unburned fuel: experimental results and implications for aerosol formation from combustion emissions, Environ. Sci. Technol., 47, 12886-12893, 2013.

Jathar, S. H., Friedman, B., Galang, A. A., Link, M. F., Brophy, P., Volckens, J., Eluri, S., and Farmer, D. K.: Linking load, fuel, and emission controls to photochemical production of secondary organic aerosol from a diesel engine, Environ. Sci. Technol., 51, 1377-1386, https://doi.org/10.1021/acs.est.6b04602, 2017.

Jayaratne, E. R., Meyer, N. K., Ristovski, Z. D., Morawska, L., and Miljevic, B.: Critical analysis of high particle number emissions from accelerating compressed natural gas buses, Environ. Sci. Technol., 44, 3724-3731, 2010.

Jayaratne, E. R., Meyer, N. K., Ristovski, Z. D., and Morawska, L.: Volatile properties of particles emitted by compressed natural gas and diesel buses during steady-state and transient driving modes, Environ. Sci. Technol., 46, 196-203, https://doi.org/10.1021/es2026856, 2012.

Jenkin, M. E., Saunders, S. M., and Pilling, M. J.: The tropospheric degradation of volatile organic compounds: a protocol for mechanism development, Atmos. Environ., 31, 81-104, https://doi.org/10.1016/S1352-2310(96)00105-7, 1997.

Jenkin, M. E., Saunders, S. M., Wagner, V., and Pilling, M. J.: Protocol for the development of the Master Chemical Mechanism, MCM v3 (Part B): tropospheric degradation of aromatic volatile organic compounds, Atmos. Chem. Phys., 3, 181-193, https://doi.org/10.5194/acp-3-181-2003, 2003.

Jimenez, J. L., Canagaratna, M. R., Donahue, N. M., Prevôt, A. S. H., Zhang, Q., Kroll, J. H., Decarlo, P. F., Allan, J. D., Coe, H., Ng, N. L., Aiken, A. C., Ulbrich, I. M., Grieshop, A. P., Duplissy, J., Wilson, K. R., Lanz, V. A., Hueglin, C., Sun, Y. L., Tian, J., Laaksonen, A., Raatikainen, T., Rautiainen, J., Vaattovaara, P., Ehn, M., Kulmala, M., Tomlinson, J. M., Cubison, M. J., Dunlea, E. J., Alfarra, M. R., Williams, P. I.,
Bower, K., Kondo, Y., Schneider, J., Drewnick, F., Borrmann, S., Weimer, S., Demerjian, K., Salcedo, D., Cottrell, L., Takami, A., Miyoshi, T., Shimono, A., Sun, J. Y., Zhang, Y. M., Dzepina, K., Sueper, D., Jayne, J. T., Herndon, S. C., Williams, L. R., Wood, E. C., Middlebrook, A. M., Kolb, C. E., Baltensperger, U., and Worsnop, D. R.: Evolution of organic aerosols in the atmosphere, Science, 326, 1525-1529, 2009.

Johnson, T. V.: Review of diesel emissions and control, Int. J. Engine Res., 10, 275-285, 2009.

Kanakidou, M., Seinfeld, J. H., Pandis, S. N., Barnes, I., Dentener, F. J., Facchini, M. C., Van Dingenen, R., Ervens, B., Nenes, A., Nielsen, C. J., Swietlicki, E., Putaud, J. P., Balkanski, Y., Fuzzi, S., Horth, J., Moortgat, G. K., Winterhalter, R., Myhre, C. E. L., Tsigaridis, K., Vignati, E., Stephanou, E. G., and Wilson, J.: Organic aerosol and global climate modelling: a review, Atmos. Chem. Phys., 5, 1053-1123, https://doi.org/10.5194/acp-5-10532005, 2005.

Kang, E., Root, M. J., Toohey, D. W., and Brune, W. H.: Introducing the concept of Potential Aerosol Mass (PAM), Atmos. Chem. Phys., 7, 5727-5744, https://doi.org/10.5194/acp-7-5727-2007, 2007.

Kang, E., Toohey, D. W., and Brune, W. H.: Dependence of SOA oxidation on organic aerosol mass concentration and $\mathrm{OH}$ exposure: experimental PAM chamber studies, Atmos. Chem. Phys., 11, 1837-1852, https://doi.org/10.5194/acp-11-1837-2011, 2011.

Karjalainen, P., Timonen, H., Saukko, E., Kuuluvainen, H., Saarikoski, S., Aakko-Saksa, P., Murtonen, T., Dal Maso, M., Ahlberg, E., Svenningsson, B., Brune, W. H., Hillamo, R., Keskinen, J., and Rönkkö, T.: Time-resolved characterization of primary and secondary particle emissions of a modern gasoline passenger car, Atmos. Chem. Phys., 16, 8559-8470, https://doi.org/10.5194/acp-16-8559-2016, 2016.

Künzi, L., Krapf, M., Daher, N., Dommen, J., Jeannet, N., Schneider, S., Platt, S., Slowik, J. G., Baumlin, N., Salathe, M., Prévôt, A. S. H., Kalberer, M., Strähl, C., Dümbgen, L., Sioutas, C., Baltensperger, U., and Geiser, M.: Toxicity of aged gasoline exhaust particles to normal and diseased airway epithelia, Sci. Rep.-UK, 5, 11801, https://doi.org/10.1038/srep11801, 2015.

Lambe, A. T., Ahern, A. T., Williams, L. R., Slowik, J. G., Wong, J. P. S., Abbatt, J. P. D., Brune, W. H., Ng, N. L., Wright, J. P., Croasdale, D. R., Worsnop, D. R., Davidovits, P., and Onasch, T. B.: Characterization of aerosol photooxidation flow reactors: heterogeneous oxidation, secondary organic aerosol formation and cloud condensation nuclei activity measurements, Atmos. Meas. Tech., 4, 445-461, https://doi.org/10.5194/amt-4445-2011, 2011.

Lambe, A. T., Chhabra, P. S., Onasch, T. B., Brune, W. H., Hunter, J. F., Kroll, J. H., Cummings, M. J., Brogan, J. F., Parmar, Y., Worsnop, D. R., Kolb, C. E., and Davidovits, P.: Effect of oxidant concentration, exposure time, and seed particles on secondary organic aerosol chemical composition and yield, Atmos. Chem. Phys., 15, 3063-3075, https://doi.org/10.5194/acp15-3063-2015, 2015.

Lehtoranta, K., Murtonen, T., Vesala, H., Koponen, P., Alanen, J., Simonen, P., Rönkkö, T., Timonen, H., Saarikoski, S., Maunula, T., Kallinen, K., and Korhonen, S.: Natural Gas Engine Emission Reduction by Catalysts, Emiss. Control Sci. Technol., 3, 142152, https://doi.org/10.1007/s40825-016-0057-8, 2017. 
Lelieveld, J., Evans, J. S., Fnais, M., Giannadaki, D., and Pozzer, A.: The contribution of outdoor air pollution sources to premature mortality on a global scale, Nature, 525, 367-71, https://doi.org/10.1038/nature15371, 2015.

Link, M. F., Kim, J., Park, G., Lee, T., Park, T., Bin, Z., Sung, K., Kim, P., Kang, S., Soo, J., Choi, Y., Son, J., Lim, H.-j., and Farmer, D. K.: Elevated production of $\mathrm{NH}_{4} \mathrm{NO}_{3}$ from the photochemical processing of vehicle exhaust: implications for air quality in the Seoul Metropolitan Region, Atmos. Environ., 156, 95-101, https://doi.org/10.1016/j.atmosenv.2017.02.031, 2017.

Mao, J., Ren, X., Brune, W. H., Olson, J. R., Crawford, J. H., Fried, A., Huey, L. G., Cohen, R. C., Heikes, B., Singh, H. B., Blake, D. R., Sachse, G. W., Diskin, G. S., Hall, S. R., and Shetter, R. E.: Airborne measurement of $\mathrm{OH}$ reactivity during INTEX-B, Atmos. Chem. Phys., 9, 163-173, https://doi.org/10.5194/acp-9163-2009, 2009.

May, A. A., Nguyen, N. T., Presto, A. A., Gordon, T. D., Lipsky, E. M., Karve, M., Gutierrez, A., Robertson, W. H., Zhang, M., Brandow, C., Chang, O., Chen, S., Cicerofernandez, P., Dinkins, L., Fuentes, M., Huang, S.-m., Ling, R., Long, J., Maddox, C., Massetti, J., Mccauley, E., Miguel, A., Na, K., Ong, R., Pang, Y., Rieger, P., Sax, T., Truong, T., Vo, T., Chattopadhyay, S., Maldonado, H., Maricq, M. M., and Robinson, A. L.: Gas- and particle-phase primary emissions from inuse, on-road gasoline and diesel vehicles, Atmos. Environ., 88, 247-260, 2014.

McWhinney, R. D., Gao, S. S., Zhou, S., and Abbatt, J. P. D.: Evaluation of the effects of ozone oxidation on redox-cycling activity of two-stroke engine exhaust particles, Environ. Sci. Technol., 45, 2131-2136, https://doi.org/10.1021/es102874d, 2011.

Middlebrook, A. M., Bahreini, R., Jimenez, J. L., and Canagaratna, M. R.: Evaluation of composition-dependent collection efficiencies for the aerodyne aerosol mass spectrometer using field data, Aerosol Sci. Tech., 46, 258-271, https://doi.org/10.1080/02786826.2011.620041, 2012.

Mikkanen, P., Moisio, M., Keskinen, J., Ristimäki, J., and Marjamäki, M.: Sampling method for particle measurements of vehicle exhaust, SAE Tech. Pap. Ser. 2001, No. 2001-01-0219, https://doi.org/10.4271/2001-01-0219, 2001.

Mirme, A.: Electrical aerosol spectrometry, PhD thesis, Dissertationes Geophysicales Universitatis Tartuensis, No. 6, University of Tartu, Estonia, 1994.

Murphy, B. N., Donahue, N. M., Robinson, A. L., and Pandis, S. N.: A naming convention for atmospheric organic aerosol, Atmos. Chem. Phys., 14, 5825-5839, https://doi.org/10.5194/acp14-5825-2014, 2014.

Murtonen, T., Lehtoranta, K., Korhonen, S., and Vesala, H.: Imitating emission matrix of large natural catalyst studies in engine laboratory, CIMAC congress, 6-10 June 2016, Helsinki, Finland, 2016.

Myhre, G., Shindell, D., Bréon, F. M., Collins, W., Fuglestvedt, J., Huang, J., Koch, D., Lamarque, J. F., Lee, D., Mendoza, B., Nakajima, T., Robock, A., Stephens, G., Takemura, T., and Zhang, H.: Anthropogenic and Natural Radiative Forcing, in: Climate Change 2013: The Physical Science Basis. Contribution of Working Group I to the Fifth Assessment Report of the Intergovernmental Panel on Climate Change, edited by: Stocker, T. F., Qin, D., Plattner, G.-K., Tignor, M., Allen, S. K., Boschung, J., Nauels, A., Xia, Y., Bex, V., and Midgley, P. M., Cambridge
University Press, Cambridge, UK and New York, NY, USA, 659740, 2013.

Nordin, E. Z., Eriksson, A. C., Roldin, P., Nilsson, P. T., Carlsson, J. E., Kajos, M. K., Hellén, H., Wittbom, C., Rissler, J., Löndahl, J., Swietlicki, E., Svenningsson, B., Bohgard, M., Kulmala, M., Hallquist, M., and Pagels, J. H.: Secondary organic aerosol formation from idling gasoline passenger vehicle emissions investigated in a smog chamber, Atmos. Chem. Phys., 13, 6101-6116, https://doi.org/10.5194/acp-13-6101-2013, 2013.

Ntziachristos, L., Giechaskiel, B., Pistikopoulos, P., Samaras, Z., Mathis, U., Mohr, M., Ristimaki, J., Keskinen, J., Mikkanen, P., Casati, R., Scheer, V., and Vogt, R.: Performance evaluation of a novel sampling and measurement system for exhaust particle characterization, SAE 2004 World Congress and Exhibition, 14 January 2004, Detroit, USA, https://doi.org/10.4271/2004-011439, 2004.

Ntziachristos, L., Saukko, E., Rönkkö, T., Lehtoranta, K., Timonen, H., Hillamo, R., and Keskinen, J.: Impact of sampling conditions and procedure on particulate matter emissions from a marine diesel engine, CIMAC congress, 6-10 June 2016, Helsinki, Finland, 2016.

Palm, B. B., Campuzano-Jost, P., Ortega, A. M., Day, D. A., Kaser, L., Jud, W., Karl, T., Hansel, A., Hunter, J. F., Cross, E. S., Kroll, J. H., Peng, Z., Brune, W. H., and Jimenez, J. L.: In situ secondary organic aerosol formation from ambient pine forest air using an oxidation flow reactor, Atmos. Chem. Phys., 16, 2943 2970, https://doi.org/10.5194/acp-16-2943-2016, 2016.

Pieber, S. M., Haddad, I. E., Slowik, J. G., Canagaratna, M. R., Jayne, J. T., Platt, S. M., Bozzetti, C., Daellenbach, K. R., Fro, R., Vlachou, A., Klein, F., Dommen, J., Miljevic, B., Jime, J. L., Worsnop, D. R., Baltensperger, U., and Prévôt, A. S. H.: Inorganic salt interference on $\mathrm{CO}_{2}^{+}$in aerodyne AMS and ACSM organic aerosol composition studies, Environ. Sci. Technol., 50, 10494-10503, https://doi.org/10.1021/acs.est.6b01035, 2016.

Pirjola, L., Dittrich, A., Niemi, J. V., Saarikoski, S., Timonen, H., Kuuluvainen, H., Järvinen, A., Kousa, A., Rönkkö, T., and Hillamo, R.: Physical and Chemical Characterization of Real-World Particle Number and Mass Emissions from City Buses in Finland, Environ. Sci. Technol., 50, 294-304, https://doi.org/10.1021/acs.est.5b04105, 2016.

Platt, S. M., El Haddad, I., Zardini, A. A., Clairotte, M., Astorga, C., Wolf, R., Slowik, J. G., Temime-Roussel, B., Marchand, N., Ježek, I., Drinovec, L., Močnik, G., Möhler, O., Richter, R., Barmet, P., Bianchi, F., Baltensperger, U., and Prévôt, A. S. H.: Secondary organic aerosol formation from gasoline vehicle emissions in a new mobile environmental reaction chamber, Atmos. Chem. Phys., 13, 9141-9158, https://doi.org/10.5194/acp13-9141-2013, 2013.

Pöschl, U., Canagaratna, M., Jayne, J. T., Molina, L. T., Worsnop, D. R., Kolb, C. E., and Molina, M. J.: Mass accommodation coefficient of $\mathrm{H}_{2} \mathrm{SO}_{4}$ vapor on aqueous sulfuric acid surfaces and gaseous diffusion coefficient of $\mathrm{H}_{2} \mathrm{SO}_{4}$ in $\mathrm{N}_{2} / \mathrm{H}_{2} \mathrm{O}$, J. Phys. Chem.-US, 102, 10082-10089, 1998.

Rager, J. E., Lichtveld, K., Ebersviller, S., Smeester, L., Jaspers, I., Sexton, K. G., and Fry, R. C.: A toxicogenomic comparison of primary and photochemically altered air pollutant mixtures, Environ. Health Persp., 119, 1583-1589, https://doi.org/10.1289/ehp.1003323, 2011. 
Robinson, A. L., Donahue, N. M., Shrivastava, M. K., Weitkamp, E. A., Sage, A. M., Grieshop, A. P., Lane, T. E., Pierce, J. R., and Pandis, S. N.: Rethinking organic aerosols: semivolatile emissions and photochemical aging, Science, 315, 1259-1262, https://doi.org/10.1126/science.1133061, 2007.

Rönkkö, T., Lähde, T., Heikkilä, J., Pirjola, L., Bauschke, U., Arnold, F., Schlager, H., Rothe, D., Yli-Ojanperä, J., and Keskinen, J.: Effects of gaseous sulphuric acid on diesel exhaust nanoparticle formation and characteristics, Environ. Sci. Technol., 47, 11882-11889, https://doi.org/10.1021/es402354y, 2013.

Samy, S. and Zielinska, B.: Secondary organic aerosol production from modern diesel engine emissions, Atmos. Chem. Phys., 10, 609-625, https://doi.org/10.5194/acp-10-609-2010, 2010.

Saunders, S. M., Jenkin, M. E., Derwent, R. G., and Pilling, M. J.: Protocol for the development of the Master Chemical Mechanism, MCM v3 (Part A): tropospheric degradation of nonaromatic volatile organic compounds, Atmos. Chem. Phys., 3, 161-180, https://doi.org/10.5194/acp-3-161-2003, 2003.

Seinfeld, J. H. and Pandis, S. N.: Atmospheric Chemistry and Physics: From Air Pollution to Climate Change, 3 edn., Wiley, New York, USA, 2016.

Simonen, P., Saukko, E., Karjalainen, P., Timonen, H., Bloss, M., Aakko-Saksa, P., Rönkkö, T., Keskinen, J., and Dal Maso, M.: A new oxidation flow reactor for measuring secondary aerosol formation of rapidly changing emission sources, Atmos. Meas. Tech., 10, 1519-1537, https://doi.org/10.5194/amt10-1519-2017, 2017.

Suarez-Bertoa, R., Zardini, A. A., Lilova, V., Meyer, D., Nakatani, S., Hibel, F., Ewers, J., Clairotte, M., Hill, L., and Astorga, C.: Intercomparison of real-time tailpipe ammonia measurements from vehicles tested over the new world-harmonized light-duty vehicle test cycle (WLTC), Environ. Sci. Pollut. R., 22, 7450-7460, 2015.

Tang, M. J., Shiraiwa, M., Pöschl, U., Cox, R. A., and Kalberer, M.: Compilation and evaluation of gas phase diffusion coefficients of reactive trace gases in the atmosphere: Volume 2. Diffusivities of organic compounds, pressure-normalised mean free paths, and average Knudsen numbers for gas uptake calculations, Atmos. Chem. Phys., 15, 5585-5598, https://doi.org/10.5194/acp15-5585-2015, 2015.
Thiruvengadam, A., Besch, M., Yoon, S., Collins, J., Kappanna, H., Carder, D., Ayala, A., Herner, J., and Gautam, M.: Characterization of particulate matter emissions from a current technology natural gas engine, Environ. Sci. Technol., 48, 8235-8242, https://doi.org/10.1021/es5005973, 2014.

Timonen, H., Karjalainen, P., Saukko, E., Saarikoski, S., AakkoSaksa, P., Simonen, P., Murtonen, T., Dal Maso, M., Kuuluvainen, H., Bloss, M., Ahlberg, E., Svenningsson, B., Pagels, J., Brune, W. H., Keskinen, J., Worsnop, D. R., Hillamo, R., and Rönkkö, T.: Influence of fuel ethanol content on primary emissions and secondary aerosol formation potential for a modern flex-fuel gasoline vehicle, Atmos. Chem. Phys., 17, 5311-5329, https://doi.org/10.5194/acp-17-5311-2017, 2017.

Tkacik, D. S., Lambe, A. T., Jathar, S., Li, X., Presto, A. A., Zhao, Y., Blake, D., Meinardi, S., Jayne, J. T., Croteau, P. L., and Robinson, A. L.: Secondary organic aerosol formation from in-use motor vehicle emissions using a potential aerosol mass reactor, Environ. Sci. Technol., 48, 11235-11242, https://doi.org/10.1021/es502239v, 2014.

Virtanen, A., Joutsensaari, J., Koop, T., Kannosto, J., Yli-Pirilä, P., Leskinen, J., Mäkelä, J. M., Holopainen, J. K., Pöschl, U., Kulmala, M., Worsnop, D. R., and Laaksonen, A.: An amorphous solid state of biogenic secondary organic aerosol particles. SI, Nature, 467, 824-7, https://doi.org/10.1038/nature09455, 2010.

Weitkamp, E. A., Sage, A. M., Pierce, J. R., Donahue, N. M., and Robinson, A. L.: Organic aerosol formation from photochemical oxidation of diesel exhaust in a smog chamber, Environ. Sci. Technol., 41, 6969-6975, https://doi.org/10.1021/es070193r, 2007.

Ziemann, P. J. and Atkinson, R.: Kinetics, products, and mechanisms of secondary organic aerosol formation, Chem. Soc. Rev., 41, 6582-6605, https://doi.org/10.1039/c2cs35122f, 2012. 